\title{
Recent Clinical Evidence in Bisphosphonate-related Osteomyelitis of the Jaw: Focus on Risk, Prevention and Treatment
}

\author{
AUTHOR(S): \\ Yamazaki, Toru; Takahashi, Katsu; Bessho, \\ Kazuhisa
}

\section{CITATION:}

Yamazaki, Toru ... [et al]. Recent Clinical Evidence in Bisphosphonate-related Osteomyelitis of the Jaw: Focus on Risk, Prevention and Treatment. Reviews on Recent Clinical Trials 2014, 9(1): 37-52

\section{ISSUE DATE:}

2014-05-31

URL:

http://hdl.handle.net/2433/199606

\section{RIGHT:}

The published manuscript is available at EurekaSelect via

http://www.eurekaselect.com/openurl/content.php?gen re=article\&doi=10.2174/1574887 109666140423120614.; この論文は出版社版でありません。引用の際には出版社版をご確 認ご利用ください。; This is not the published version. Please cite only the published version. 
Recent clinical evidence in bisphosphonate-related osteomyelitis of the jaw: focus on risk, prevention and treatment.

Running title: Recent clinical evidence in bisphosphonate-related osteomyelitis of the jaw

Author list: Toru Yamazaki, DDS, Ph.D., Katsu Takahashi, DDS, Ph.D., Kazuhisa Bessho, DDS, DMSc

Department of Oral and Maxillofacial Surgery,

Graduate School of Medicine, Kyoto University,

54 Shogoin Kawahara-cho, Sakyo-ku, Kyoto 606-8507, Japan

Corresponding Author: Toru Yamazaki

Affiliation address:

Department of Oral and Maxillofacial Surgery,

Graduate School of Medicine, Kyoto University,

54 Shogoin Kawahara-cho, Sakyo-ku, Kyoto 606-8507, Japan

Tel: +81-75-751-3408

Fax: +81-75-761-9732

Email: toruy@kuhp.kyoto-u.ac.jp 


\begin{abstract}
Bisphosphonates (BPs) are widely used for the treatment of a range of conditions involving bone, such as osteoporosis and bone metastases of cancer, and their efficacy has been confirmed. Nevertheless, a first case of bisphosphonate-related osteonecrosis of the jaw (BRONJ) as an adverse effect of BP treatment was reported in 2003, and several clinical studies since then have elaborated the risk, prevention and treatment of BRONJ or bisphosphonate-related osteomyelitis of the jaw (BROMJ). However, effective decision making on BP risk is hampered by a lack of accurate information for patients, physicians or dentists. Furthermore, the narrow definition of BRONJ used to date has precluded the wider development of clinical research on risk.

In this review, we discuss current issues in BROMJ, with a focus on risk, prevention and treatment. In particular, we reconsider the definition of BRONJ from the standpoint of clinical evidence. Finally, we propose a new strategy for the treatment of BROMJ.
\end{abstract}

\title{
Key Words
}

Absolute risk, Bisphosphonate, Osteonecrosis of the jaw, Prevention, Prognosis, Relative risk, Risk factors, Treatment 


\section{Introduction}

Bisphosphonate (BPs) are widely used for the prevention and treatment of a range of bone conditions, including postmenopausal osteoporosis, Paget disease, hypercalcemia in malignancies, and osteolytic bone metastases of cancer or multiple myeloma $[1,2]$. BPs can be administered orally and intravenously in a wide range of doses, dosing intervals, and duration of administration [1]. The biologic action of BPs is to suppress farnesyl pyrophosphate synthase in the mevalonate biosynthetic pathway and inhibit the resorption of bone via the inactivation of osteoclasts [3]. Although this action accounts for the preventive or therapeutic efficacy of these agents, it also accounts for their uncommon skeletal-related events (SRE) or adverse effects $[1,2]$. In particular, cases of osteonecrosis of the jaw (ONJ) have been reported as possible adverse effect of BPs since 2003 [4]. This condition is presently defined by the presence of exposed bone in the maxillofacial region for six to eight weeks [5-10], and patients with ONJ often encounter difficulties in sustaining their quality of life (QOL) [11].

Due to a lack of information, BP-related ONJ (BRONJ) was initially considered difficult to treat, similarly to osteoradionecrosis of the jaw, and to be a largely different condition to osteomyelitis of the jaw (OMJ) $[4,12,13]$. Regrettably, however, a number of organizations, national regulatory agencies, medical specialty societies and clinicians disseminated information on the risk of BPs for ONJ without accurate data on incidence, risk factors, prognosis, or treatment [14], and thereby confounded both patients treated with BPs and medical and dental professionals. Many relevant studies and reviews have since appeared, however, and these early problems have been progressively resolved.

In this paper, we review clinical studies of BRONJ or BP-related OMJ (BROMJ) over the last 10 years, outline the problems identified, and then discuss current issues in BRONJ and BROMJ, with a focus on risk, prevention and treatment. In particular, we discuss the definition of BRONJ from the standpoint of clinical evidence. Finally, we propose a new strategy for the treatment of BROMJ. 


\section{Methods}

Literature search strategy and research questions

A systematic search of the English literature was conducted. The MEDLINE/PUBMED and Scopus databases were searched from January 1, 2003 to December 31, 2012. In the MEDLINE search, we entered the following Medical Subject Headings (MeSH): "diphosphonates"[MeSH Terms] OR "diphosphonates"[All Fields] OR "bisphosphonate"[All Fields] OR "bisphosphonate-associated osteonecrosis of the jaw"[MeSH Terms] OR "bisphosphonate-associated"[All Fields] AND ("jaw"[MeSH Terms] OR "jaw"[All Fields]) AND (hasabstract[text] AND "humans"[MeSH Terms] AND English[lang])). We additionally searched studies published from January 1, 2012 to December 31, 2012 in the Scopus database by using the following key words: (TITLE-ABS-KEY-AUTH("osteonecrosis of the jaw" OR "osteomyelitis of the jaw" OR "inflammation of the jaw") AND (LIMIT-TO(PUBYEAR,2012)) AND (LIMIT-TO(LANGUAGE, "English")).

Titles and abstracts were reviewed to determine relevance. The search for clinical evidence included randomized controlled trials (RCT), cohort studies, case-control studies, cross-sectional studies, case series and literature reviews. Letters, animal studies and basic studies were excluded.

Our research questions in the review were as follows:

1. How much of the absolute risk of BROMJ is estimated to be accounted for by users of intravenous BPs?

2. How much of the absolute risk of BROMJ is estimated to be accounted for by users of oral BPs?

3. How much of the relative risk of OMJ is estimated by the incidence of OMJ in BPs users compared to non-users, regardless of BP type?

4. What are the risk factors of BROMJ?

5. Are there any prognosis markers for the incidence of BROMJ?

6. Are there any effective preventive measures for the incidence of BROMJ?

7. Are there any effective treatments for BROMJ?

8. Are there any new treatments for BROMJ?

In the review, we investigated the following information: year of electronic publication, country, setting, type of study, target population and number, main endpoint, diagnostician, type of BP, search procedure of BPs, risk index, risk ratio, risk factors, prognosis, and treatments. In addition, the evidence grade of studies 
was classified according to the 2010 American Heart Association guideline [15]. Here, we define metaanalyses as evidence 1a, RCTs as 1b, cohort studies as 2, and case-control studies as 3 .

A unit of incidence rates was converted into the unit "per million person-years". All statistical analyses were performed using Stata 11.2 software (Stata Corporation, College Station, TX, USA). 


\section{Results and Discussion}

\section{Definition of epidemiological terms}

To aid understanding of this literature review, we first explain the epidemiological terms cumulative incidence, prevalence, incidence rate, absolute risk and relative risk, as follows.

Cumulative incidence refers to the number or proportion of a group (cohort) of people who experience the onset of a health-related event during a specified time interval [16]. In contrast, prevalence refers to the total number of individuals who have an attribute or disease at a particular time or particular period divided by the population at risk of having the attribute or disease at that time or midway through the period, respectively [16]. Although the term "prevalence" is thus inherently different from "cumulative incidence" in meaning, we include "prevalence" in "cumulative incidence" here because of the severely limited number of cross-sectional studies identified in the literature review. In contrast, incidence rate refers to the rate at which a new event occurs in a population, and is quite different from "cumulative incidence". Accordingly, we distinguish the term "incidence rate" from "cumulative incidence" in the review [16].

These risks are then grouped as "absolute risk", which means the number of events in a group divided by the total number of subjects in that group [16]. Moreover, we use the term "relative risk" to evaluate the risk of BPs for OMJ. This means the ratio of the risk of an event among the exposed to that among the unexposed [16].

\section{History and Definitions of BROMJ}

In 2003, Marx first suggested a possible association between the use of intravenous BPs and avascular necrosis of the jaw [4], and described 36 patients receiving pamidronate or zoledronate who had exposure of necrotic bone in the oral cavity. Since this sensational report, hundreds of cases of BRONJ cases have been reported [17-30] and a number of clinical studies published between 2003 and 2006 demonstrated the absolute risk or risk factors of BRONJ among patients using intravenous BPs [31-38]. In the same period, the manufacturers or the US Food and Drug Administration indicated the presence of a safety concern regarding the use of BPs [14]. Furthermore, some expert panels recommended the prevention and treatment of BP-associated ONJ notwithstanding that evidence for the association was limited, particularly among users of oral BPs [19, 20, 39-41]. Finally, in 2007, a position paper by the American Association of Oral 
and Maxillofacial Surgeons (AAOMS) proposed the establishment of BRONJ as a new disease entity with the following three characteristics: 1) current or previous treatment with a bisphosphonate; 2) exposed, necrotic bone in the maxillofacial region that has persisted for more than 8 weeks; and 3) no history of radiation therapy to the jaw [42]. Following this position paper, several associations stated definitions of BRONJ, BP-associated ONJ, or BP-ONJ which, despite the differences in naming, were commonly defined by the presence of exposed bone in the maxillofacial region [5-10, 43].

Here, we propose grouping cases of OMJ together with ONJ, because we consider it difficult to distinguish ONJ from OMJ, for two reasons: first, radiographic findings in infected jawbone in patients treated with BPs are similar to those in BP-induced ONJ even if necrotic bone cannot be clinically visualized [44-46]; and second, the presence of osteonecrosis is a common histopathologic finding in both BP-induced ONJ and OMJ [47]. These finding suggest that the condition of bone exposure in the oral cavity is not always caused by avascular necrosis of the jaw. Several studies or reviews have also regarded ONJ as the same as OMJ [48-51]. We therefore need to reconsider the definition of "BRONJ" according to this recent clinical evidence and pathological findings of the condition; in particular, such early identification of OMJ without long-term exposure of necrotic bone may be relevant to treatment.

How much of the absolute risk of BROMJ is estimated to be accounted for by users of intravenous BPs?

Accumulated evidence has clarified that the risk of BROMJ is higher in patients taking intravenous BPs than oral BPs [37, 52-54]. In addition, most patients receiving intravenous BPs were considered to have cancer [7] and be at higher risk for infectious disease than those taking oral BPs. We therefore discuss incidence by route of administration.

Table 1 show characteristics of the literature concerning cumulative risk of BROMJ among patients taking intravenous BPs. A total of 91 papers describing the cumulative risk of BROMJ were identified [10, $31,32,34-37,49,53-135]$, the largest number of which came from the US, followed by Italy, Greece and other countries. Most studies were conducted in hospitals, and were aimed at investigating the cumulative incidence or risk factors of BROMJ. More than half of the 91 studies were cohort studies, although almost none of these had a control group, in other words patients who were not treated with BPs. Further, 21 of the 91 studies were conducted as RCTs, but with efficacy of BPs or SREs as main outcome, and the 
incidence of BROMJ as a secondary endpoint only. The cumulative incidence of BROMJ in those studies ranged from $0 \%$ to $51.8 \%$, or the incidence rate ranged from 0.70 per 100 patients to 5.5 per 1,000 personyears.

We summarized the characteristics of studies of BROMJ among patients taking intravenous BPs which had an evidence level of 3 or better (Table 2 and 3). The cumulative incidence of BROMJ in multicenter RCTs was extremely low, ranging from $0 \%$ to $3.5 \%$, with a median incidence of $0.6 \%$ (Table 2). In contrast, the cumulative incidence of BROMJ in controlled, observational studies ranged from $0.34 \%$ to $14.8 \%$, with a median incidence of 5.0\% (Table 3). These findings appear to indicate a large difference between these studies in absolute risk.

We speculate that the difference in absolute risk between studies is partly due to differences among the investigators of BROMJ in the various studies. In particular, the diagnostic criteria for BROMJ or the background of those diagnosing BROMJ was unclear in prospective studies because BROMJ was just one SRE or secondary endpoint. This might have resulted in underestimation of the incidence of BROMJ. In addition, we suspect that differences in the settings or target populations of the studies mainly influenced absolute risk; in other words, participants in the clinical trials may have been generally healthier than the subjects of the clinical observational studies. On the other hand, the subjects in clinical observational studies may have had several primary illnesses and required substantial medical treatment, including BPs. Moreover, differences between these studies may have resulted from differences in the duration of exposure to BPs, although we were unable to investigate duration in detail. To sum up, any interpretation of our results should be done with due regard to study design, setting, target population, sample size, definition of outcome, and diagnostician.

Denosumab is a human monoclonal antibody against receptor activator of nuclear factor kappa-B ligand. Several studies have shown the superiority of this agent to BPs in the treatment of bone metastases and prevention of SRE in cancer patients $[105,111,112,119,134]$. Notably, these studies have also indicated that denosumab has a similar risk for OMJ as BPs. The absolute risk of OMJ was estimated to range from $0.8 \%$ to $2.3 \%$. Given that evidence for the risk of OMJ with denosumab remains limited, however, particular vigilance against the possibility of adverse effects in these patients is required. 
How much of the absolute risk of BROMJ is estimated to be accounted for by users of oral BPs?

The cumulative incidence of BROMJ in patients taking oral BPs ranged from $0 \%$ to $7.8 \%[10,37,51$, $54,62,106,136-150]$, or the incidence rate ranged from 6.3 to 366 per million person-years [53, 146, 151, 152]. We abstracted those studies with an evidence level of 3 or better (Table 4), among which cumulative incidence was estimated to range from $0 \%$ to $4.3 \%$, or the incidence rate from 6.3 to 366 per million personyears.

Due to the low occurrence of BROMJ in patients treated with oral BPs, initial studies estimated incidence by anticipating the total number of individuals who had been prescribed oral BPs [62, 144]. More recently, however, population-based or larger hospital-based studies, as well as administrative data have allowed an understanding of the absolute risk of BROMJ in patients taking oral BPs $[51,53,106,146,151$, 152]. From these studies and our previous study, the cumulative risk of OMJ with oral BPs is less than $1 \%$ in patients with osteoporosis, and the incidence risk is considered to be low.

How much of the relative risk of OMJ is estimated by the incidence of OMJ in BPs users compared to nonusers, regardless of BP type?

A meta-analysis which extracted data from $15 \mathrm{RCTs}(\mathrm{n}=10,694)$ showed that treatment with zoledronic acid was significantly associated with the occurrence of ONJ $(\mathrm{M}-\mathrm{H}$ pooled odds ratios $(\mathrm{OR})=3.2,95 \%$ confidence interval (CI), 1.7-8) compared with no use [98]. In contrast, a meta-analysis of other data extracted from three RCTs $(n=736)$ showed no significant association between intravenous BPs and ONJ (pooled relative risks $(\mathrm{RR})=4.0,95 \% \mathrm{CI}, 0.44-35.8)$ [2]. Six observational studies reported the relative risk of BROMJ in patients treated with intravenous BPs while 10 observational studies reported the risk in patients treated with oral BPs (Table 5). The estimated OR, RR or hazard risks in patients treated with intravenous BPs ranged from 1.6 (95\% CI, 0.71-3.8) to 299.5 (95\% CI, 70-1282). Of these studies, only one found no significant association between intravenous BPs and OMJ [118], whereas the rest showed an increased risk of OMJ with intravenous BPs, with significance [37, 49, 52-54, 153]. Similarly, four studies found no significant or inverse association between oral BPs and OMJ [37, 53, 54, 154], whereas the rest showed an increased risk of OMJ with oral BPs, ranging from 2.2 (95\% CI, 1.2-4.3) to 15.5 (95\% CI, 6.038.7) [50,51, 146, 151-153]. Overall, both intravenous and oral BPs may increase the risk of OMJ, although 
these studies slightly differed in endpoint characteristics (e.g. OMJ or Jaw surgery code), sample size, target population and number, and presence of adjustment for confounding. A conclusive answer awaits additional meta-analysis or larger clinical observational studies.

What are the risk factors of BROMJ?

More than one hundred studies have examined risk factors associated with BROMJ or prognosis. In particular, diabetes, cancer chemotherapy, corticosteroids, and thalidomide have all been suggested to be risk factors $[31,35,50,51,53,56,60,63,70,75,86,87,110,125,128,146,153,155-165]$. Unfortunately, however, most of these studies evaluated risk factors without adjustment for confounding factors or controls, which may have introduced bias into judgment or decision-making. We therefore summarized the possible risk factors for BROMJ in controlled studies with consideration to potential confounding factors (Table 6).

Most studies have shown that BPs with high potency or prolonged duration/no. of cycles increase the risk of BROMJ. These findings may be supported by the dose-response or strength association and coherence. On the other hand, findings for the association between other possible risk factors and BROMJ lack consistency. For example, some studies found an association between other possible risk factors such as use of cancer chemotherapy and BROMJ $[50,56,60,161]$, whereas others did not $[54,63,70,75,110$, $153,158,160,162]$. Similarly, associations between other demographic factors such as sex, age or race and BROMJ are also controversial. With regard to oral status, many studies reported that the use of a denture, severe periodontal status, and surgical dental treatments such as tooth extraction may be risk factors of BROMJ, whereas others showed no significant association between periodontal status, caries, or root canal treatment and BROMJ. Overall, almost all these factors were investigated as possible confounding factors or secondary endpoints in the studies, but given that some surveys were conducted using questionnaires, interview, or chart review, and most definitions of factors were not described in detail, the accuracy of some diagnoses might have been low. In addition, many studies may have had insufficient statistical power to evaluate risk factors for BROMJ. These results should therefore be interpreted with care. Larger, welldesigned controlled studies targeting factors involved in or associated with the induction of BROMJ are required. 
Are there any prognosis markers for the incidence of BROMJ?

C-terminal telopeptide (CTX) and other bone markers such as N-terminal telopeptide (NTX) or bonespecific alkaline phosphatase (BAP) were first reported as possible prognostic markers of BROMJ in 2007 [166]. Our review process identified seven relevant studies appearing since then [145, 167-173]. Among these, however, three studies were characterized as case series without controls [166-168] and the rest were case-control studies without adjustment for confounding factors [145, 169-173]. We were therefore unable to find sufficient evidence to support the hypothesis that suppression of CTX, NTX, BAP or other bone makers was a prognostic marker of BROMJ. One possibility is that although local bone turnover in the jaw might be suppressed, this local turnover has no impact on biochemical markers which reflect systemic bone turnover [172].

With regard to genetic factors, nine studies have identified differences in genetic polymorphisms in case-control studies, and shown associations between some genes and the risk of BROMJ [73, 174-181]. These results suggest that the risk of BROMJ is increased by genes encoding for cytochrome P450 and aromatase, as well as RBMS3, IGFBP7, ABCC4, COL1A1, RANK, MMP2, OPG, OPN, CYP2C8, and NFAT2. These genes, which are associated with drug or bone metabolism, are possible prognosis markers of BROMJ, albeit that sample sizes in these studies were low $[179,180]$.

Are there any effective preventive measures for the incidence of BROMJ?

A drug holiday from BPs has been reported to prevent BROMJ [5, 7]; in particular, one study found that a three-month washout period before surgical treatment prevented the incidence of BROMJ [166]. Here, however, we found no clinical evidence to support this hypothesis. Biologically, BPs are considered to accumulate in skeletal sites that have active bone remodeling, and to remain there for a long time $[9,47$, 152]. Present knowledge therefore provides little evidence to support the use of a three-month drug holiday to wash-out BPs from skeletal sites, and to support its clinical efficacy in the prevention of BROMJ.

Several reports investigated the effectiveness of oral care in the prevention of BROMJ $[77,82,83,182$, 183]. Although these studies were all conducted in single centers and did not consider other confounding factors, they nevertheless had sufficient sample sizes to examine the hypothesis, and all showed significant risk reductions by interventional preventive oral care. Although direct evidence that the severity of oral 
hygiene or periodontal status increases the incidence of BROMJ remains limited [54, 162, 184], these reports suggest that poor oral hygiene and a severe periodontal status are risk factors for BROMJ and that dental care prevents the incidence of BROMJ.

Are there any effective treatments for BROMJ?

Table 7 summarizes controlled studies which aimed to evaluate the treatment of BROMJ [79, 171, 185191]. Almost all studies demonstrated that surgical treatment was effective [186, 188-191]: while they differed in surgical treatment method, indications, and target populations, they all showed a common relationship between the presence of preoperative inflammation and prognosis of BROMJ, and found that successful treatment was more frequent when antibiotic therapy and/or oral care was provided before surgery. These results suggest that the control of local inflammation plays a crucial role in ensuring a positive prognosis for BROMJ after surgical treatment.

One RCT showed that hyperbaric oxygen (HBO) therapy was effective for the treatment of BROMJ, as judged by a decrease in lesion size, number, and pain, and improvement in QOL [185]. Unfortunately, however, this study did not have a sufficient sample size $(n=49)$ to allow for adjustment of confounding factors. Two mechanisms for this effectiveness have been proposed. First, the produced reactive oxygen and nitrogen species signal osteoclast differentiation, activity and viability. Second, HBO therapy ameliorates edema and inflammation, augments microbial killing and invokes stem cell mobilization, vasculogenesis and tissue repair in other wounds [185]. Further large, well-designed controlled studies to investigate the effectiveness of surgical treatment or HBO therapy are required.

\section{Are there any new treatments for BROMJ?}

Recent studies have reported that parathyroid hormone (teriparatide) is effective in in patients with BROMJ [192-198]. One of these studies was a case report and the rest were case series, however, and their level of clinical evidence was accordingly insufficient to confirm this efficacy. Interestingly, these studies did confirm the presence of bone regeneration in inflammatory regions at more than 2 months after subcutaneous injection of teriparatide into patients with BROMJ. The ongoing accumulation of case reports and case-series, or stronger evidence, might allow a better understanding of the pathogenesis of BROMJ 
and a new approach to its treatment.

Our proposal for the diagnosis, prevention and treatment of BROMJ in the early stage

From the accumulated clinical evidence in this review, we propose the following diagnosis, prevention and treatment strategy for BROMJ in the early stage (Figure 1). Compared to the AAOMS's strategy in 2009 [7], the four hierarchical diagnostic criteria defined below allow OMJ to be identified earlier, without the need for long-term exposure of necrotic bone [51]:

1. possible cases are diagnosed by increased uptake on technetium bone scan with characteristic signs and symptoms of bone infection, and/or findings on dental panoramic X-ray.

2. probable cases are diagnosed by imaging findings on computed tomography or magnetic resonance imaging scans which are consistent with findings of possible cases.

3. confirmed cases are diagnosed by a histological picture consistent with OMJ and/or the isolation of microorganisms in samples obtained by extraoral open surgery, percutaneous biopsy of bone, excised bone or intramedullary tissue, or pus aspiration from adjacent tissues, with findings of probable cases

4. cases which do not meet the above criteria are not considered as cases of OMJ.

Diagnosis of OMJ is often difficult, however, particularly in the early stage [199], and these criteria are not always consistently applied to different stages of OMJ. Osteomyelitis is caused by a certain inciting focus that enables the infection to propagate but has various clinical expressions, and the clinical characteristics and laboratory features of infection are not always present $[199,200]$. This background explains why diagnostic imaging has long played a major role in the investigation of suspected osteomyelitis [201]. CT or MRI scans were of greater value in diagnosing OMJ than technetium bone scans or plain radiographs, but the highest priority was given to a histological picture consistent with OMJ and/or the isolation of a microorganism in samples [199-201].

The early identification of BROMJ using objective imaging or histological findings might also enable the use of more aggressive treatment, such as HBO therapy or surgical treatment if indicated, which might in turn lead to a better treatment response.

\section{Conclusions}


We conducted a systematic review of previous clinical studies of BROMJ over 10 years with a focus on risk, prevention and treatment. The still-accumulating evidence suggests that all types of BP increase the risk of OMJ incidence. Prevention of BROMJ might be aided by oral care before and after BP administration. Once a symptomatic condition in the jaw occurs, however, the use of technetium bone scan and CT or MRI findings may be useful in evaluating the condition in its early stage. After local inflammation is controlled with antibiotic therapy and/or oral care, surgical treatment may be valid. Biological and interventional studies suggest that HBO may be a useful adjunctive therapy during the disease course in encouraging bone remodeling and wound healing. Further investigations of the prevention and treatment of BROMJ in larger, prospective, well-designed controlled studies are required.

\section{List of Abbreviations}

AAOMS, American Association of Oral and Maxillofacial Surgeons; BAP, bone-specific alkaline phosphatase; BPs, bisphosphonates; BROMJ, bisphosphonate-related osteomyelitis of the jaw; BRONJ, bisphosphonate-related osteonecrosis of the jaw; CI, confidence interval; CTX, C-terminal telopeptide; HBO, hyperbaric oxygen; NTX, N-terminal telopeptide; OMJ, osteomyelitis of the jaw; ONJ, osteonecrosis of the jaw; OR, odds ratios; QOL, quality of life; RCT, randomized controlled trial; RR, relative risks; SRE, skeletal-related events.

Conflicts of interests

All authors declare that there are no financial relationships with any organizations that might have an interest in the submitted work and no other relationships or activities that could appear to have influenced the submitted work. 
References

1. Rudic JS, Giljaca V, Krstic MN, Bjelakovic G, Gluud C. Bisphosphonates for osteoporosis in primary biliary cirrhosis. Cochrane Database Syst Rev. 2011(12):CD009144.

2. Mhaskar R, Redzepovic J, Wheatley K, Clark OA, Miladinovic B, Glasmacher A, et al. Bisphosphonates in multiple myeloma: a network meta-analysis. Cochrane Database Syst Rev. 2012;5:CD003188.

3. Russell RG. Bisphosphonates: the first 40 years. Bone. 2011;49(1):2-19.

4. Marx RE. Pamidronate (Aredia) and zoledronate (Zometa) induced avascular necrosis of the jaws: a growing epidemic. J Oral Maxillofac Surg. 2003;61(9):1115-7.

5. Khosla S, Burr D, Cauley J, Dempster DW, Ebeling PR, Felsenberg D, et al. Bisphosphonateassociated osteonecrosis of the jaw: report of a task force of the American Society for Bone and Mineral Research. J Bone Miner Res. 2007;22(10):1479-91.

6. Rizzoli R, Burlet N, Cahall D, Delmas PD, Eriksen EF, Felsenberg D, et al. Osteonecrosis of the jaw and bisphosphonate treatment for osteoporosis. Bone. 2008;42(5):841-7.

7. Ruggiero SL, Dodson TB, Assael LA, Landesberg R, Marx RE, Mehrotra B, et al. American Association of Oral and Maxillofacial Surgeons position paper on bisphosphonate-related osteonecrosis of the jaws--2009 update. J Oral Maxillofac Surg. 2009;67(5 Suppl):2-12.

8. Campisi G, Fedele S, Colella G, Casto AL, Fusco V. Canadian consensus practice guidelines for bisphosphonate associated osteonecrosis of the jaw. J Rheumatol. 2009;36(2):451-3; author reply 3.

9. Yoneda T, Hagino H, Sugimoto T, Ohta H, Takahashi S, Soen S, et al. Bisphosphonate-related osteonecrosis of the jaw: position paper from the Allied Task Force Committee of Japanese Society for Bone and Mineral Research, Japan Osteoporosis Society, Japanese Society of Periodontology, Japanese Society for Oral and Maxillofacial Radiology, and Japanese Society of Oral and Maxillofacial Surgeons. J Bone Miner Metab. 2010;28(4):365-83.

10. Khan AA, Rios LP, Sándor GK, Khan N, Peters E, Rahman MO, et al. Bisphosphonate-associated osteonecrosis of the jaw in Ontario: a survey of oral and maxillofacial surgeons. J Rheumatol. 2011;38(7):1396-402.

11. Miksad RA, Lai KC, Dodson TB, Woo SB, Treister NS, Akinyemi O, et al. Quality of life implications of bisphosphonate-associated osteonecrosis of the jaw. Oncologist. 2011;16(1):121-32.

12. Agrillo A, Petrucci MT, Tedaldi M, Mustazza MC, Marino SM, Gallucci C, et al. New therapeutic protocol in the treatment of avascular necrosis of the jaws. J Craniofac Surg. 2006;17(6):10803.

13. Affairs ADACoS. Dental management of patients receiving oral bisphosphonate therapy: expert panel recommendations. J Am Dent Assoc. 2006;137(8):1144-50.

14. Edwards BJ, Gounder M, McKoy JM, Boyd I, Farrugia M, Migliorati C, et al. Pharmacovigilance and reporting oversight in US FDA fast-track process: bisphosphonates and osteonecrosis of the jaw. Lancet Oncol. 2008;9(12):1166-72.

15. Sayre MR, O'Connor RE, Atkins DL, Billi JE, Callaway CW, Shuster M, et al. Part 2: evidence evaluation and management of potential or perceived conflicts of interest: 2010 American Heart Association Guidelines for Cardiopulmonary Resuscitation and Emergency Cardiovascular Care. Circulation. 2010;122(18 Suppl 3):S657-64.

16. Miquel Porta, editors. A dictionary of Epidemiology. 5th ed. Oxford: Oxford University Press; 2008.

17. Hellstein JW, Marek CL. Bis-phossy jaw, phossy jaw, and the 21st century: bisphosphonateassociated complications of the jaws. J Oral Maxillofac Surg. 2004;62(12):1563-5.

18. Ruggiero SL, Mehrotra B, Rosenberg TJ, Engroff SL. Osteonecrosis of the jaws associated with the use of bisphosphonates: a review of 63 cases. J Oral Maxillofac Surg. 2004;62(5):527-34.

19. Melo MD, Obeid G. Osteonecrosis of the jaws in patients with a history of receiving bisphosphonate therapy: strategies for prevention and early recognition. $\mathrm{J}$ Am Dent Assoc. 2005;136(12):1675-81.

20. Markiewicz MR, Margarone JE, Campbell JH, Aguirre A. Bisphosphonate-associated osteonecrosis of the jaws: a review of current knowledge. J Am Dent Assoc. 2005;136(12):1669-74.

21. Marx RE, Sawatari Y, Fortin M, Broumand V. Bisphosphonate-induced exposed bone (osteonecrosis/osteopetrosis) of the jaws: risk factors, recognition, prevention, and treatment. J Oral 
Maxillofac Surg. 2005;63(11):1567-75.

22. Ficarra G, Beninati F, Rubino I, Vannucchi A, Longo G, Tonelli P, et al. Osteonecrosis of the jaws in periodontal patients with a history of bisphosphonates treatment. J Clin Periodontol. 2005;32(11):1123-8.

23. Sarathy AP, Bourgeois SL, Goodell GG. Bisphosphonate-associated osteonecrosis of the jaws and endodontic treatment: two case reports. J Endod. 2005;31(10):759-63.

24. Bagan JV, Murillo J, Jimenez Y, Poveda R, Milian MA, Sanchis JM, et al. Avascular jaw osteonecrosis in association with cancer chemotherapy: series of 10 cases. J Oral Pathol Med. 2005;34(2):120-3.

25. Graziani F, Cei S, La Ferla F, Cerri E, Itro A, Gabriele M. Association between osteonecrosis of the jaws and chronic high-dosage intravenous bisphosphonates therapy. J Craniofac Surg. 2006;17(5):8769.

26. Capalbo S, Delia M, Diomede D, Dargenio M, Chiefa A, Favia G, et al. Jaw osteonecrosis associated with use of bisphosphonates and chemotherapy: paradoxical complication of treatment of bone lesions in multiple myeloma patients. Int J Hematol. 2006;83(5):439-42.

27. Bagan JV, Jimenez Y, Murillo J, Hernandez S, Poveda R, Sanchis JM, et al. Jaw osteonecrosis associated with bisphosphonates: multiple exposed areas and its relationship to teeth extractions. Study of 20 cases. Oral Oncol. 2006;42(3):327-9.

28. Dimitrakopoulos I, Magopoulos C, Karakasis D. Bisphosphonate-induced avascular osteonecrosis of the jaws: a clinical report of 11 cases. Int J Oral Maxillofac Surg. 2006;35(7):588-93.

29. Thakkar SG, Isada C, Smith J, Karam MA, Reed J, Tomford JW, et al. Jaw complications associated with bisphosphonate use in patients with plasma cell dyscrasias. Med Oncol. 2006;23(1):51-6.

30. Zarychanski R, Elphee E, Walton P, Johnston J. Osteonecrosis of the jaw associated with pamidronate therapy. Am J Hematol. 2006;81(1):73-5.

31. Bamias A, Kastritis E, Bamia C, Moulopoulos LA, Melakopoulos I, Bozas G, et al. Osteonecrosis of the jaw in cancer after treatment with bisphosphonates: incidence and risk factors. J Clin Oncol. 2005;23(34):8580-7.

32. Guarneri V, Donati S, Nicolini M, Giovannelli S, D'Amico R, Conte PF. Renal safety and efficacy of i.v. bisphosphonates in patients with skeletal metastases treated for up to 10 Years. Oncologist. 2005;10(10):842-8.

33. Tosi P, Zamagni E, Cangini D, Tacchetti P, Di Raimondo F, Catalano L, et al. Osteonecrosis of the jaws in newly diagnosed multiple myeloma patients treated with zoledronic acid and thalidomidedexamethasone. Blood. 2006;108(12):3951-2.

34. Sanna G, Preda L, Bruschini R, Cossu Rocca M, Ferretti S, Adamoli L, et al. Bisphosphonates and jaw osteonecrosis in patients with advanced breast cancer. Ann Oncol. 2006;17(10):1512-6.

35. Zervas K, Verrou E, Teleioudis Z, Vahtsevanos K, Banti A, Mihou D, et al. Incidence, risk factors and management of osteonecrosis of the jaw in patients with multiple myeloma: a single-centre experience in 303 patients. Br J Haematol. 2006;134(6):620-3.

36. Dimopoulos MA, Kastritis E, Anagnostopoulos A, Melakopoulos I, Gika D, Moulopoulos LA, et al. Osteonecrosis of the jaw in patients with multiple myeloma treated with bisphosphonates: evidence of increased risk after treatment with zoledronic acid. Haematologica. 2006;91(7):968-71.

37. Zavras AI, Zhu S. Bisphosphonates are associated with increased risk for jaw surgery in medical claims data: is it osteonecrosis? J Oral Maxillofac Surg. 2006;64(6):917-23.

38. Badros A, Weikel D, Salama A, Goloubeva O, Schneider A, Rapoport A, et al. Osteonecrosis of the jaw in multiple myeloma patients: clinical features and risk factors. J Clin Oncol. 2006;24(6):945-52.

39. Migliorati CA, Casiglia J, Epstein J, Jacobsen PL, Siegel MA, Woo SB. Managing the care of patients with bisphosphonate-associated osteonecrosis: an American Academy of Oral Medicine position paper. J Am Dent Assoc. 2005;136(12):1658-68.

40. Ruggiero S, Gralow J, Marx RE, Hoff AO, Schubert MM, Huryn JM, et al. Practical guidelines for the prevention, diagnosis, and treatment of osteonecrosis of the jaw in patients with cancer. J Oncol Pract. 2006;2(1):7-14.

41. Woo SB, Hellstein JW, Kalmar JR. Narrative [corrected] review: bisphosphonates and osteonecrosis of the jaws. Ann Intern Med. 2006;144(10):753-61.

42. Advisory Task Force on Bisphosphonate-Related Ostenonecrosis of the Jaws AeAoOaMS. American Association of Oral and Maxillofacial Surgeons position paper on bisphosphonate-related 
osteonecrosis of the jaws. J Oral Maxillofac Surg. 2007;65(3):369-76.

43. McLeod NM, Patel V, Kusanale A, Rogers SN, Brennan PA. Bisphosphonate osteonecrosis of the jaw: a literature review of UK policies versus international policies on the management of bisphosphonate osteonecrosis of the jaw. Br J Oral Maxillofac Surg. 2011;49(5):335-42.

44. Junquera L, Gallego L. Nonexposed bisphosphonate-related osteonecrosis of the jaws: another clinical variant? J Oral Maxillofac Surg. 2008;66(7):1516-7.

45. Mawardi H, Treister N, Richardson P, Anderson K, Munshi N, Faiella RA, et al. Sinus tracts--an early sign of bisphosphonate-associated osteonecrosis of the jaws? J Oral Maxillofac Surg. 2009;67(3):593601.

46. Hutchinson M, O'Ryan F, Chavez V, Lathon PV, Sanchez G, Hatcher DC, et al. Radiographic findings in bisphosphonate-treated patients with stage 0 disease in the absence of bone exposure. $\mathrm{J}$ Oral Maxillofac Surg. 2010;68(9):2232-40.

47. Bertoldo F, Santini D, Lo Cascio V. Bisphosphonates and osteomyelitis of the jaw: a pathogenic puzzle. Nat Clin Pract Oncol. 2007;4(12):711-21.

48. Department of Health and Human Services PHO, Food and Drug Administration. ODS postmarketing safety review 2004 [cited 2012 December/1]. Available at: http://www.fda.gov/ohrms/dockets/ac/05/briefing/2005-4095B2_03_04-FDA-TAB3.pdf].

49. Wilkinson GS, Kuo YF, Freeman JL, Goodwin JS. Intravenous bisphosphonate therapy and inflammatory conditions or surgery of the jaw: a population-based analysis. J Natl Cancer Inst. 2007;99(13):1016-24.

50. Vestergaard P, Schwartz K, Rejnmark L, Mosekilde L, Pinholt EM. Oral bisphosphonate use increases the risk for inflammatory jaw disease: a cohort study. J Oral Maxillofac Surg. 2012;70(4):821-9.

51. Yamazaki T, Yamori M, Yamamoto K, Saito K, Asai K, Sumi E, et al. Risk of osteomyelitis of the jaw induced by oral bisphosphonates in patients taking medications for osteoporosis: a hospital-based cohort study in Japan. Bone. 2012;51(5):882-7.

52. Cartsos VM, Zhu S, Zavras AI. Bisphosphonate use and the risk of adverse jaw outcomes: a medical claims study of 714,217 people. J Am Dent Assoc. 2008;139(1):23-30.

53. Tennis P, Rothman KJ, Bohn RL, Tan H, Zavras A, Laskarides C, et al. Incidence of osteonecrosis of the jaw among users of bisphosphonates with selected cancers or osteoporosis. Pharmacoepidemiol Drug Saf. 2012;21(8):810-7.

54. Yamazaki T, Yamori M, Ishizaki T, Asai K, Goto K, Takahashi K, et al. Increased incidence of osteonecrosis of the jaw after tooth extraction in patients treated with bisphosphonates: a cohort study. Int J Oral Maxillofac Surg. 2012;41(11):1397-403.

55. Walter C, Grötz KA, Kunkel M, Al-Nawas B. Prevalence of bisphosphonate associated osteonecrosis of the jaw within the field of osteonecrosis. Support Care Cancer. 2007;15(2):197-202.

56. Aguiar Bujanda D, Bohn Sarmiento U, Cabrera Suárez MA, Aguiar Morales J. Assessment of renal toxicity and osteonecrosis of the jaws in patients receiving zoledronic acid for bone metastasis. Ann Oncol. 2007;18(3):556-60.

57. Corso A, Varettoni M, Zappasodi P, Klersy C, Mangiacavalli S, Pica G, et al. A different schedule of zoledronic acid can reduce the risk of the osteonecrosis of the jaw in patients with multiple myeloma. Leukemia. 2007;21(7):1545-8.

58. Tassinari D, Poggi B, Nicoletti S, Fantini M, Tamburini E, Possenti C, et al. Zoledronic acid treatment at home: safety data from an observational prospective trial. J Palliat Med. 2007;10(2):352-8.

59. Israeli RS, Rosenberg SJ, Saltzstein DR, Gottesman JE, Goldstein HR, Hull GW, et al. The effect of zoledronic acid on bone mineral density in patients undergoing androgen deprivation therapy. Clin Genitourin Cancer. 2007;5(4):271-7.

60. Jadu F, Lee L, Pharoah M, Reece D, Wang L. A retrospective study assessing the incidence, risk factors and comorbidities of pamidronate-related necrosis of the jaws in multiple myeloma patients. Ann Oncol. 2007;18(12):2015-9.

61. Lyles KW, Colón-Emeric CS, Magaziner JS, Adachi JD, Pieper CF, Mautalen C, et al. Zoledronic acid and clinical fractures and mortality after hip fracture. N Engl J Med. 2007;357(18):1799-809.

62. Mavrokokki T, Cheng A, Stein B, Goss A. Nature and frequency of bisphosphonate-associated osteonecrosis of the jaws in Australia. J Oral Maxillofac Surg. 2007;65(3):415-23.

63. Ortega C, Montemurro F, Faggiuolo R, Vormola R, Nanni D, Goia F, et al. Osteonecrosis of the jaw in prostate cancer patients with bone metastases treated with zoledronate: a retrospective analysis. Acta 
Oncol. 2007;46(5):664-8.

64. Pozzi S, Marcheselli R, Sacchi S, Baldini L, Angrilli F, Pennese E, et al. Bisphosphonateassociated osteonecrosis of the jaw: a review of 35 cases and an evaluation of its frequency in multiple myeloma patients. Leuk Lymphoma. 2007;48(1):56-64.

65. Wang EP, Kaban LB, Strewler GJ, Raje N, Troulis MJ. Incidence of osteonecrosis of the jaw in patients with multiple myeloma and breast or prostate cancer on intravenous bisphosphonate therapy. J Oral Maxillofac Surg. 2007;65(7):1328-31.

66. Murad OM, Arora S, Farag AF, Guber HA. Bisphosphonates and osteonecrosis of the jaw: a retrospective study. Endocr Pract. 2007;13(3):232-8.

67. Addeo R, Nocera V, Faiola V, Vincenzi B, Ferraro G, Montella L, et al. Management of pain in elderly patients receiving infusion of zoledronic acid for bone metastasis: a single-institution report. Support Care Cancer. 2008;16(2):209-14.

68. Brown JJ, Ramalingam L, Zacharin MR. Bisphosphonate-associated osteonecrosis of the jaw: does it occur in children? Clin Endocrinol (Oxf). 2008;68(6):863-7.

69. Grbic JT, Landesberg R, Lin SQ, Mesenbrink P, Reid IR, Leung PC, et al. Incidence of osteonecrosis of the jaw in women with postmenopausal osteoporosis in the health outcomes and reduced incidence with zoledronic acid once yearly pivotal fracture trial. J Am Dent Assoc. 2008;139(1):32-40.

70. Boonyapakorn T, Schirmer I, Reichart PA, Sturm I, Massenkeil G. Bisphosphonate-induced osteonecrosis of the jaws: prospective study of 80 patients with multiple myeloma and other malignancies. Oral Oncol. 2008;44(9):857-69.

71. Cafro AM, Barbarano L, Nosari AM, D'Avanzo G, Nichelatti M, Bibas M, et al. Osteonecrosis of the jaw in patients with multiple myeloma treated with bisphosphonates: definition and management of the risk related to zoledronic acid. Clin Lymphoma Myeloma. 2008;8(2):111-6.

72. Brufsky A, Bundred N, Coleman R, Lambert-Falls R, Mena R, Hadji P, et al. Integrated analysis of zoledronic acid for prevention of aromatase inhibitor-associated bone loss in postmenopausal women with early breast cancer receiving adjuvant letrozole. Oncologist. 2008;13(5):503-14.

73. Sarasquete ME, García-Sanz R, Marín L, Alcoceba M, Chillón MC, Balanzategui A, et al. Bisphosphonate-related osteonecrosis of the jaw is associated with polymorphisms of the cytochrome $\mathrm{P} 450$ CYP2C8 in multiple myeloma: a genome-wide single nucleotide polymorphism analysis. Blood. 2008;112(7):2709-12.

74. Estilo CL, Van Poznak CH, Wiliams T, Bohle GC, Lwin PT, Zhou Q, et al. Osteonecrosis of the maxilla and mandible in patients with advanced cancer treated with bisphosphonate therapy. Oncologist. 2008;13(8):911-20.

75. Hoff AO, Toth BB, Altundag K, Johnson MM, Warneke CL, Hu M, et al. Frequency and risk factors associated with osteonecrosis of the jaw in cancer patients treated with intravenous bisphosphonates. J Bone Miner Res. 2008;23(6):826-36.

76. Ibrahim T, Barbanti F, Giorgio-Marrano G, Mercatali L, Ronconi S, Vicini C, et al. Osteonecrosis of the jaw in patients with bone metastases treated with bisphosphonates: a retrospective study. Oncologist. 2008;13(3):330-6.

77. La Verde N, Bareggi C, Garassino M, Borgonovo K, Sburlati P, Pedretti D, et al. Osteonecrosis of the jaw (ONJ) in cancer patients treated with Bisphosphonates: how the knowledge of a phenomenon can change its evolution. Support Care Cancer. 2008;16(11):1311-5.

78. Malmgren B, Aström E, Söderhäll S. No osteonecrosis in jaws of young patients with osteogenesis imperfecta treated with bisphosphonates. J Oral Pathol Med. 2008;37(4):196-200.

79. Montefusco V, Gay F, Spina F, Miceli R, Maniezzo M, Teresa Ambrosini M, et al. Antibiotic prophylaxis before dental procedures may reduce the incidence of osteonecrosis of the jaw in patients with multiple myeloma treated with bisphosphonates. Leuk Lymphoma. 2008;49(11):2156-62.

80. Musto P, Petrucci MT, Bringhen S, Guglielmelli T, Caravita T, Bongarzoni V, et al. A multicenter, randomized clinical trial comparing zoledronic acid versus observation in patients with asymptomatic myeloma. Cancer. 2008;113(7):1588-95.

81. Walter C, Al-Nawas B, Grötz KA, Thomas C, Thüroff JW, Zinser V, et al. Prevalence and risk factors of bisphosphonate-associated osteonecrosis of the jaw in prostate cancer patients with advanced disease treated with zoledronate. Eur Urol. 2008;54(5):1066-72.

82. Ripamonti CI, Maniezzo M, Campa T, Fagnoni E, Brunelli C, Saibene G, et al. Decreased occurrence of osteonecrosis of the jaw after implementation of dental preventive measures in solid tumour 
patients with bone metastases treated with bisphosphonates. The experience of the National Cancer Institute of Milan. Ann Oncol. 2009;20(1):137-45.

83. Dimopoulos MA, Kastritis E, Bamia C, Melakopoulos I, Gika D, Roussou M, et al. Reduction of osteonecrosis of the jaw (ONJ) after implementation of preventive measures in patients with multiple myeloma treated with zoledronic acid. Ann Oncol. 2009;20(1):117-20.

84. Berenson JR, Yellin O, Boccia RV, Flam M, Wong SF, Batuman O, et al. Zoledronic acid markedly improves bone mineral density for patients with monoclonal gammopathy of undetermined significance and bone loss. Clin Cancer Res. 2008;14(19):6289-95.

85. Chahine C, Cheung MS, Head TW, Schwartz S, Glorieux FH, Rauch F. Tooth extraction socket healing in pediatric patients treated with intravenous pamidronate. J Pediatr. 2008;153(5):719-20.

86. Cetiner S, Sucak GT, Kahraman SA, Aki SZ, Kocakahyaoglu B, Gultekin SE, et al. Osteonecrosis of the jaw in patients with multiple myeloma treated with zoledronic acid. J Bone Miner Metab. 2009;27(4):435-43.

87. Christodoulou C, Pervena A, Klouvas G, Galani E, Falagas ME, Tsakalos G, et al. Combination of bisphosphonates and antiangiogenic factors induces osteonecrosis of the jaw more frequently than bisphosphonates alone. Oncology. 2009;76(3):209-11.

88. Crawford BS, McNulty RM, Kraut EH, Turowski RC. Extended use of intravenous bisphosphonate therapy for the prevention of skeletal complications in patients with cancer. Cancer Invest. 2009;27(10):984-8.

89. Fehm T, Beck V, Banys M, Lipp HP, Hairass M, Reinert S, et al. Bisphosphonate-induced osteonecrosis of the jaw (ONJ): Incidence and risk factors in patients with breast cancer and gynecological malignancies. Gynecol Oncol. 2009;112(3):605-9.

90. Stumpe MR, Chandra RK, Yunus F, Samant S. Incidence and risk factors of bisphosphonateassociated osteonecrosis of the jaws. Head Neck. 2009;31(2):202-6.

91. Vahtsevanos K, Kyrgidis A, Verrou E, Katodritou E, Triaridis S, Andreadis CG, et al. Longitudinal cohort study of risk factors in cancer patients of bisphosphonate-related osteonecrosis of the jaw. J Clin Oncol. 2009;27(32):5356-62.

92. Walter C, Al-Nawas B, du Bois A, Buch L, Harter P, Grötz KA. Incidence of bisphosphonateassociated osteonecrosis of the jaws in breast cancer patients. Cancer. 2009;115(8):1631-7.

93. Hines SL, Mincey B, Dentchev T, Sloan JA, Perez EA, Johnson DB, et al. Immediate versus delayed zoledronic acid for prevention of bone loss in postmenopausal women with breast cancer starting letrozole after tamoxifen-N03CC. Breast Cancer Res Treat. 2009;117(3):603-9.

94. Aragon-Ching JB, Ning YM, Chen CC, Latham L, Guadagnini JP, Gulley JL, et al. Higher incidence of Osteonecrosis of the Jaw (ONJ) in patients with metastatic castration resistant prostate cancer treated with anti-angiogenic agents. Cancer Invest. 2009;27(2):221-6.

95. Bonomi M, Nortilli R, Molino A, Sava T, Santo A, Caldara A, et al. Renal toxicity and osteonecrosis of the jaw in cancer patients treated with bisphosphonates: a long-term retrospective analysis. Med Oncol. 2010;27(2):224-9.

96. Brufsky AM, Bosserman LD, Caradonna RR, Haley BB, Jones CM, Moore HC, et al. Zoledronic acid effectively prevents aromatase inhibitor-associated bone loss in postmenopausal women with early breast cancer receiving adjuvant letrozole: Z-FAST study 36-month follow-up results. Clin Breast Cancer. 2009;9(2):77-85.

97. Johannesen J, Briody J, McQuade M, Little DG, Cowell CT, Munns CF. Systemic effects of zoledronic acid in children with traumatic femoral head avascular necrosis and Legg-Calve-Perthes disease. Bone. 2009;45(5):898-902.

98. Mauri D, Valachis A, Polyzos IP, Polyzos NP, Kamposioras K, Pesce LL. Osteonecrosis of the jaw and use of bisphosphonates in adjuvant breast cancer treatment: a meta-analysis. Breast Cancer Res Treat. 2009;116(3):433-9.

99. Haidar A, Jønler M, Folkmar TB, Lund L. Bisphosphonate (zoledronic acid)-induced osteonecrosis of the jaw. Scand J Urol Nephrol. 2009;43(6):442-4.

100. Saia G, Blandamura S, Bettini G, Tronchet A, Totola A, Bedogni G, et al. Occurrence of bisphosphonate-related osteonecrosis of the jaw after surgical tooth extraction. J Oral Maxillofac Surg. 2010;68(4):797-804.

101. Guarneri V, Miles D, Robert N, Diéras V, Glaspy J, Smith I, et al. Bevacizumab and osteonecrosis of the jaw: incidence and association with bisphosphonate therapy in three large prospective trials in 
advanced breast cancer. Breast Cancer Res Treat. 2010;122(1):181-8.

102. Baqain ZH, Sawair FA, Tamimi Z, Bsoul N, Al Edwan G, Almasad JK, et al. Osteonecrosis of jaws related to intravenous bisphosphonates: the experience of a Jordanian teaching hospital. Ann R Coll Surg Engl. 2010;92(6):489-94.

103. Lazarovici TS, Yahalom R, Taicher S, Schwartz-Arad D, Peleg O, Yarom N. Bisphosphonaterelated osteonecrosis of the jaw associated with dental implants. J Oral Maxillofac Surg. 2010;68(4):7906.

104. Gimsing P, Carlson K, Turesson I, Fayers P, Waage A, Vangsted A, et al. Effect of pamidronate $30 \mathrm{mg}$ versus $90 \mathrm{mg}$ on physical function in patients with newly diagnosed multiple myeloma (Nordic Myeloma Study Group): a double-blind, randomised controlled trial. Lancet Oncol. 2010;11(10):973-82.

105. Stopeck AT, Lipton A, Body JJ, Steger GG, Tonkin K, de Boer RH, et al. Denosumab compared with zoledronic acid for the treatment of bone metastases in patients with advanced breast cancer: a randomized, double-blind study. J Clin Oncol. 2010;28(35):5132-9.

106. Skrepnek GH, Seal B, Tangirala M, Jeffcoat MK, Watts NB, Hay JW. Adverse events and intravenous versus oral bisphosphonate use in patients with osteoporosis and cancer in the U.S. Gen Dent. 2010;58(6):484-92; quiz 93-4.

107. Scoletta M, Arduino PG, Pol R, Arata V, Silvestri S, Chiecchio A, et al. Initial experience on the outcome of teeth extractions in intravenous bisphosphonate-treated patients: a cautionary report. J Oral Maxillofac Surg. 2011;69(2):456-62.

108. Morgan GJ, Davies FE, Gregory WM, Cocks K, Bell SE, Szubert AJ, et al. First-line treatment with zoledronic acid as compared with clodronic acid in multiple myeloma (MRC Myeloma IX): a randomised controlled trial. Lancet. 2010;376(9757):1989-99.

109. Orita Y, Sugitani I, Toda K, Manabe J, Fujimoto Y. Zoledronic acid in the treatment of bone metastases from differentiated thyroid carcinoma. Thyroid. 2011;21(1):31-5.

110. Berenson JR, Yellin O, Crowley J, Makary A, Gravenor DS, Yang HH, et al. Prognostic factors and jaw and renal complications among multiple myeloma patients treated with zoledronic acid. Am J Hematol. 2011;86(1):25-30.

111. Henry DH, Costa L, Goldwasser F, Hirsh V, Hungria V, Prausova J, et al. Randomized, doubleblind study of denosumab versus zoledronic acid in the treatment of bone metastases in patients with advanced cancer (excluding breast and prostate cancer) or multiple myeloma. J Clin Oncol. 2011;29(9):1125-32.

112. Fizazi K, Carducci M, Smith M, Damião R, Brown J, Karsh L, et al. Denosumab versus zoledronic acid for treatment of bone metastases in men with castration-resistant prostate cancer: a randomised, double-blind study. Lancet. 2011;377(9768):813-22.

113. Coleman R, Woodward E, Brown J, Cameron D, Bell R, Dodwell D, et al. Safety of zoledronic acid and incidence of osteonecrosis of the jaw (ONJ) during adjuvant therapy in a randomised phase III trial (AZURE: BIG 01-04) for women with stage II/III breast cancer. Breast Cancer Res Treat. 2011;127(2):429-38.

114. Nicolatou-Galitis O, Papadopoulou E, Sarri T, Boziari P, Karayianni A, Kyrtsonis MC, et al. Osteonecrosis of the jaw in oncology patients treated with bisphosphonates: prospective experience of a dental oncology referral center. Oral Surg Oral Med Oral Pathol Oral Radiol Endod. 2011;112(2):195-202. 115. Gnant M, Mlineritsch B, Stoeger H, Luschin-Ebengreuth G, Heck D, Menzel C, et al. Adjuvant endocrine therapy plus zoledronic acid in premenopausal women with early-stage breast cancer: 62-month follow-up from the ABCSG-12 randomised trial. Lancet Oncol. 2011;12(7):631-41.

116. Pivot X, Lortholary A, Abadie-Lacourtoisie S, Mefti-Lacheraf F, Pujade-Lauraine E, Lefeuvre $\mathrm{C}$, et al. Renal safety of ibandronate $6 \mathrm{mg}$ infused over $15 \mathrm{~min}$ versus $60 \mathrm{~min}$ in breast cancer patients with bone metastases: a randomized open-label equivalence trial. Breast. 2011;20(6):510-4.

117. Quispe D, Shi R, Burton G. Osteonecrosis of the jaw in patients with metastatic breast cancer: ethnic and socio-economic aspects. Breast J. 2011;17(5):510-3.

118. Baillargeon J, Kuo YF, Lin YL, Wilkinson GS, Goodwin JS. Osteonecrosis of the jaw in older osteoporosis patients treated with intravenous bisphosphonates. Ann Pharmacother. 2011;45(10):1199-206. 119. Saad F, Brown JE, Van Poznak C, Ibrahim T, Stemmer SM, Stopeck AT, et al. Incidence, risk factors, and outcomes of osteonecrosis of the jaw: integrated analysis from three blinded active-controlled phase III trials in cancer patients with bone metastases. Ann Oncol. 2012;23(5):1341-7.

120. Brufsky AM, Harker WG, Beck JT, Bosserman L, Vogel C, Seidler C, et al. Final 5-year results 
of Z-FAST trial: adjuvant zoledronic acid maintains bone mass in postmenopausal breast cancer patients receiving letrozole. Cancer. 2012;118(5):1192-201.

121. Bantis A, Zissimopoulos A, Sountoulides P, Kalaitzis C, Giannakopoulos S, Deftereos S, et al. Bisphosphonate-induced osteonecrosis of the jaw in patients with bone metastatic, hormone-sensitive prostate cancer. Risk factors and prevention strategies. Tumori. 2011;97(4):479-83.

122. Coleman RE, Marshall H, Cameron D, Dodwell D, Burkinshaw R, Keane M, et al. Breast-cancer adjuvant therapy with zoledronic acid. N Engl J Med. 2011;365(15):1396-405.

123. Safra T, Bernstein-Molho R, Greenberg J, Pelles-Avraham S, Stephansky I, Sarid D, et al. The protective effect of zoledronic acid on bone loss in postmenopausal women with early breast cancer treated with sequential tamoxifen and letrozole: a prospective, randomized, phase II trial. Oncology. 2011;81(56):298-305.

124. Teoh G, Chen Y, Kim K, Srivastava A, Pai VR, Yoon SS, et al. Lower dose dexamethasone/thalidomide and zoledronic acid every 3 weeks in previously untreated multiple myeloma. Clin Lymphoma Myeloma Leuk. 2012;12(2):118-26.

125. Thumbigere-Math V, Tu L, Huckabay S, Dudek AZ, Lunos S, Basi DL, et al. A retrospective study evaluating frequency and risk factors of osteonecrosis of the jaw in 576 cancer patients receiving intravenous bisphosphonates. Am J Clin Oncol. 2012;35(4):386-92.

126. Gammelager H, Erichsen R, Antonsen S, Nørholt SE, Neumann-Jensen B, Ehrenstein V, et al. Positive predictive value of the International Classification of Diseases, 10th revision, codes to identify osteonecrosis of the jaw in patients with cancer. Cancer Epidemiol. 2012;36(4):381-3.

127. Ding X, Fan Y, Ma F, Li Q, Wang J, Zhang P, et al. Prolonged administration of bisphosphonates is well-tolerated and effective for skeletal-related events in Chinese breast cancer patients with bone metastasis. Breast. 2012;21(4):544-9.

128. Miyazaki H, Nishimatsu H, Kume H, Suzuki M, Fujimura T, Fukuhara H, et al. Leukopenia as a risk factor for osteonecrosis of the jaw in metastatic prostate cancer treated using zoledronic acid and docetaxel. BJU Int. 2012.

129. Vincenzi B, Napolitano A, Zoccoli A, Iuliani M, Pantano F, Papapietro N, et al. Serum VEGF levels as predictive marker of bisphosphonate-related osteonecrosis of the jaw. J Hematol Oncol. 2012;5:56. 130. Powell D, Bowler C, Roberts T, Garton M, Matthews C, McCall I, et al. Incidence of serious side effects with intravenous bisphosphonate: a clinical audit. QJM. 2012;105(10):965-71.

131. Young J, Nickman NA, Biskupiak JE, Barney RB, Gaffney DK, Namjoshi M, et al. Characterization of clinical course and usual care patterns in female metastatic breast cancer patients treated with zoledronic acid. Breast. 2012.

132. Then C, Hörauf N, Otto S, Pautke C, von Tresckow E, Röhnisch T, et al. Incidence and risk factors of bisphosphonate-related osteonecrosis of the jaw in multiple myeloma patients having undergone autologous stem cell transplantation. Onkologie. 2012;35(11):658-64.

133. Beuselinck B, Wolter P, Karadimou A, Elaidi R, Dumez H, Rogiers A, et al. Concomitant oral tyrosine kinase inhibitors and bisphosphonates in advanced renal cell carcinoma with bone metastases. $\mathrm{Br}$ J Cancer. 2012;107(10):1665-71.

134. Scagliotti GV, Hirsh V, Siena S, Henry DH, Woll PJ, Manegold C, et al. Overall survival improvement in patients with lung cancer and bone metastases treated with denosumab versus zoledronic acid: subgroup analysis from a randomized phase 3 study. J Thorac Oncol. 2012;7(12):1823-9.

135. Scagliotti GV, Kosmidis P, de Marinis F, Schreurs AJ, Albert I, Engel-Riedel W, et al. Zoledronic acid in patients with stage IIIA/B NSCLC: results of a randomized, phase III study. Ann Oncol. 2012;23(8):2082-7.

136. Jeffcoat MK. Safety of oral bisphosphonates: controlled studies on alveolar bone. Int J Oral Maxillofac Implants. 2006;21(3):349-53.

137. Yao S, McCarthy PL, Dunford LM, Roy DM, Brown K, Paplham P, et al. High prevalence of early-onset osteopenia/osteoporosis after allogeneic stem cell transplantation and improvement after bisphosphonate therapy. Bone Marrow Transplant. 2008;41(4):393-8.

138. Wells GA, Cranney A, Peterson J, Boucher M, Shea B, Robinson V, et al. Alendronate for the primary and secondary prevention of osteoporotic fractures in postmenopausal women. Cochrane Database Syst Rev. 2008(1):CD001155.

139. Wells G, Cranney A, Peterson J, Boucher M, Shea B, Robinson V, et al. Risedronate for the primary and secondary prevention of osteoporotic fractures in postmenopausal women. Cochrane Database 
Syst Rev. 2008(1):CD004523.

140. Bell BM, Bell RE. Oral bisphosphonates and dental implants: a retrospective study. J Oral Maxillofac Surg. 2008;66(5):1022-4.

141. Sedghizadeh PP, Stanley K, Caligiuri M, Hofkes S, Lowry B, Shuler CF. Oral bisphosphonate use and the prevalence of osteonecrosis of the jaw: an institutional inquiry. $\mathrm{J}$ Am Dent Assoc. 2009;140(1):61-6.

142. Hong JW, Nam W, Cha IH, Chung SW, Choi HS, Kim KM, et al. Oral bisphosphonate-related osteonecrosis of the jaw: the first report in Asia. Osteoporos Int. 2010;21(5):847-53.

143. Lo JC, O'Ryan FS, Gordon NP, Yang J, Hui RL, Martin D, et al. Prevalence of osteonecrosis of the jaw in patients with oral bisphosphonate exposure. J Oral Maxillofac Surg. 2010;68(2):243-53.

144. Goss A, Bartold M, Sambrook P, Hawker P. The nature and frequency of bisphosphonateassociated osteonecrosis of the jaws in dental implant patients: a South Australian case series. J Oral Maxillofac Surg. 2010;68(2):337-43.

145. Lazarovici TS, Mesilaty-Gross S, Vered I, Pariente C, Kanety H, Givol N, et al. Serologic bone markers for predicting development of osteonecrosis of the jaw in patients receiving bisphosphonates. $\mathrm{J}$ Oral Maxillofac Surg. 2010;68(9):2241-7.

146. Fellows JL, Rindal DB, Barasch A, Gullion CM, Rush W, Pihlstrom DJ, et al. ONJ in two dental practice-based research network regions. J Dent Res. 2011;90(4):433-8.

147. Malden N, Lopes V. An epidemiological study of alendronate-related osteonecrosis of the jaws. A case series from the south-east of Scotland with attention given to case definition and prevalence. J Bone Miner Metab. 2012;30(2):171-82.

148. Lo JC, O'Ryan F, Yang J, Hararah MK, Gonzalez JR, Gordon N, et al. Oral health considerations in older women receiving oral bisphosphonate therapy. J Am Geriatr Soc. 2011;59(5):916-22.

149. Paterson AH, Anderson SJ, Lembersky BC, Fehrenbacher L, Falkson CI, King KM, et al. Oral clodronate for adjuvant treatment of operable breast cancer (National Surgical Adjuvant Breast and Bowel Project protocol B-34): a multicentre, placebo-controlled, randomised trial. Lancet Oncol. 2012;13(7):73442.

150. Hansen PJ, Knitschke M, Draenert FG, Irle S, Neff A. Incidence of bisphosphonate-related osteonecrosis of the jaws (BRONJ) in patients taking bisphosphonates for osteoporosis treatment-a grossly underestimated risk? Clin Oral Investig. 2012.

151. Etminan M, Aminzadeh K, Matthew IR, Brophy JM. Use of oral bisphosphonates and the risk of aseptic osteonecrosis: a nested case-control study. J Rheumatol. 2008;35(4):691-5.

152. Lapi F, Cipriani F, Caputi AP, Corrao G, Vaccheri A, Sturkenboom MC, et al. Assessing the risk of osteonecrosis of the jaw due to bisphosphonate therapy in the secondary prevention of osteoporotic fractures. Osteoporos Int. 2012.

153. Barasch A, Cunha-Cruz J, Curro FA, Hujoel P, Sung AH, Vena D, et al. Risk factors for osteonecrosis of the jaws: a case-control study from the CONDOR dental PBRN. J Dent Res. 2011;90(4):439-44.

154. Pazianas M, Blumentals WA, Miller PD. Lack of association between oral bisphosphonates and osteonecrosis using jaw surgery as a surrogate marker. Osteoporos Int. 2008;19(6):773-9.

155. Allegra A, Oteri G, Nastro E, Alonci A, Bellomo G, Del Fabro V, et al. Patients with bisphosphonates-associated osteonecrosis of the jaw have reduced circulating endothelial cells. Hematol Oncol. 2007;25(4):164-9.

156. Khamaisi M, Regev E, Yarom N, Avni B, Leitersdorf E, Raz I, et al. Possible association between diabetes and bisphosphonate-related jaw osteonecrosis. J Clin Endocrinol Metab. 2007;92(3):1172-5.

157. Abu-Id MH, Warnke PH, Gottschalk J, Springer I, Wiltfang J, Acil Y, et al. "Bis-phossy jaws" high and low risk factors for bisphosphonate-induced osteonecrosis of the jaw. J Craniomaxillofac Surg. 2008;36(2):95-103.

158. Kos M, Brusco D, Kuebler J, Engelke W. Clinical comparison of patients with osteonecrosis of the jaws, with and without a history of bisphosphonates administration. Int J Oral Maxillofac Surg. 2010;39(11):1097-102.

159. Watters AL, Hansen HJ, Williams T, Chou JF, Riedel E, Halpern J, et al. Intravenous bisphosphonate-related osteonecrosis of the jaw: Long-term follow-up of 109 patients. Oral Surg Oral Med Oral Pathol Oral Radiol. 2013;115(2):192-200.

160. Wessel JH, Dodson TB, Zavras AI. Zoledronate, smoking, and obesity are strong risk factors for 
osteonecrosis of the jaw: a case-control study. J Oral Maxillofac Surg. 2008;66(4):625-31.

161. Van den Wyngaert T, Claeys T, Huizing MT, Vermorken JB, Fossion E. Initial experience with conservative treatment in cancer patients with osteonecrosis of the jaw (ONJ) and predictors of outcome. Ann Oncol. 2009;20(2):331-6.

162. Urade M, Tanaka N, Furusawa K, Shimada J, Shibata T, Kirita T, et al. Nationwide survey for bisphosphonate-related osteonecrosis of the jaws in Japan. J Oral Maxillofac Surg. 2011;69(11):e364-71.

163. Kyrgidis A, Vahtsevanos K, Koloutsos G, Andreadis C, Boukovinas I, Teleioudis Z, et al. Bisphosphonate-related osteonecrosis of the jaws: a case-control study of risk factors in breast cancer patients. J Clin Oncol. 2008;26(28):4634-8.

164. Fleisher KE, Jolly A, Venkata UD, Norman RG, Saxena D, Glickman RS. Osteonecrosis of the jaw onset times are based on the route of bisphosphonate therapy. J Oral Maxillofac Surg. 2013;71(3):5139.

165. Sedghizadeh PP, Jones AC, Lavallee C, Jelliffe RW, Le AD, Lee P, et al. Population pharmacokinetic and pharmacodynamic modeling for assessing risk of bisphosphonate-related osteonecrosis of the jaw. Oral Surg Oral Med Oral Pathol Oral Radiol. 2013;115(2):224-32.

166. Marx RE, Cillo JE, Ulloa JJ. Oral bisphosphonate-induced osteonecrosis: risk factors, prediction of risk using serum CTX testing, prevention, and treatment. J Oral Maxillofac Surg. 2007;65(12):2397-410. 167. Kwon YD, Kim DY, Ohe JY, Yoo JY, Walter C. Correlation between serum C-terminal crosslinking telopeptide of type I collagen and staging of oral bisphosphonate-related osteonecrosis of the jaws. J Oral Maxillofac Surg. 2009;67(12):2644-8.

168. Fleisher KE, Welch G, Kottal S, Craig RG, Saxena D, Glickman RS. Predicting risk for bisphosphonate-related osteonecrosis of the jaws: CTX versus radiographic markers. Oral Surg Oral Med Oral Pathol Oral Radiol Endod. 2010;110(4):509-16.

169. Lee CY, Suzuki JB. CTX biochemical marker of bone metabolism. Is it a reliable predictor of bisphosphonate-associated osteonecrosis of the jaws after surgery? Part II: a prospective clinical study. Implant Dent. 2010;19(1):29-38.

170. Kwon YD, Ohe JY, Kim DY, Chung DJ, Park YD. Retrospective study of two biochemical markers for the risk assessment of oral bisphosphonate-related osteonecrosis of the jaws: can they be utilized as risk markers? Clin Oral Implants Res. 2011;22(1):100-5.

171. Atalay B, Yalcin S, Emes Y, Aktas I, Aybar B, Issever H, et al. Bisphosphonate-related osteonecrosis: laser-assisted surgical treatment or conventional surgery? Lasers Med Sci. 2011;26(6):81523.

172. Morris PG, Fazio M, Farooki A, Estilo C, Mallam D, Conlin A, et al. Serum N-telopeptide and bone-specific alkaline phosphatase levels in patients with osteonecrosis of the jaw receiving bisphosphonates for bone metastases. J Oral Maxillofac Surg. 2012;70(12):2768-75.

173. O'Connell JE, Ikeagwani O, Kearns GJ. A role for C-terminal cross-linking telopeptide (CTX) level to predict the development of bisphosphonate-related osteonecrosis of the jaws (BRONJ) following oral surgery? Ir J Med Sci. 2012;181(2):237-42.

174. Raje N, Woo SB, Hande K, Yap JT, Richardson PG, Vallet S, et al. Clinical, radiographic, and biochemical characterization of multiple myeloma patients with osteonecrosis of the jaw. Clin Cancer Res. 2008;14(8):2387-95.

175. Marini F, Tonelli P, Cavalli L, Cavalli T, Masi L, Falchetti A, et al. Pharmacogenetics of bisphosphonate-associated osteonecrosis of the jaw. Front Biosci (Elite Ed). 2011;3:364-70.

176. Katz J, Gong Y, Salmasinia D, Hou W, Burkley B, Ferreira P, et al. Genetic polymorphisms and other risk factors associated with bisphosphonate induced osteonecrosis of the jaw. Int J Oral Maxillofac Surg. 2011;40(6):605-11.

177. Arduino PG, Menegatti E, Scoletta M, Battaglio C, Mozzati M, Chiecchio A, et al. Vascular endothelial growth factor genetic polymorphisms and haplotypes in female patients with bisphosphonaterelated osteonecrosis of the jaws. J Oral Pathol Med. 2011;40(6):510-5.

178. Such E, Cervera J, Terpos E, Bagán JV, Avaria A, Gómez I, et al. CYP2C8 gene polymorphism and bisphosphonate-related osteonecrosis of the jaw in patients with multiple myeloma. Haematologica. 2011;96(10):1557-9.

179. Nicoletti P, Cartsos VM, Palaska PK, Shen Y, Floratos A, Zavras AI. Genomewide pharmacogenetics of bisphosphonate-induced osteonecrosis of the jaw: the role of RBMS3. Oncologist. 2012;17(2):279-87. 
180. Balla B, Vaszilko M, Kósa JP, Podani J, Takács I, Tóbiás B, et al. New approach to analyze genetic and clinical data in bisphosphonate-induced osteonecrosis of the jaw. Oral Dis. 2012;18(6):580-5. 181. La Ferla F, Paolicchi E, Crea F, Cei S, Graziani F, Gabriele M, et al. An aromatase polymorphism (g.132810C $>\mathrm{T})$ predicts risk of bisphosphonate-related osteonecrosis of the jaw. Biomark Med. 2012;6(2):201-9.

182. Bonacina R, Mariani U, Villa F, Villa A. Preventive strategies and clinical implications for bisphosphonate-related osteonecrosis of the jaw: a review of 282 patients. J Can Dent Assoc. 2011;77:b147. 183. Vandone AM, Donadio M, Mozzati M, Ardine M, Polimeni MA, Beatrice S, et al. Impact of dental care in the prevention of bisphosphonate-associated osteonecrosis of the jaw: a single-center clinical experience. Ann Oncol. 2012;23(1):193-200.

184. Hasegawa T, Ri S, Umeda M, Komatsubara H, Kobayashi M, Shigeta T, et al. The observational study of delayed wound healing after tooth extraction in patients receiving oral bisphosphonate therapy. J Craniomaxillofac Surg. 2013.

185. Freiberger JJ, Padilla-Burgos R, McGraw T, Suliman HB, Kraft KH, Stolp BW, et al. What is the role of hyperbaric oxygen in the management of bisphosphonate-related osteonecrosis of the jaw: a randomized controlled trial of hyperbaric oxygen as an adjunct to surgery and antibiotics. J Oral Maxillofac Surg. 2012;70(7):1573-83.

186. Wutzl A, Biedermann E, Wanschitz F, Seemann R, Klug C, Baumann A, et al. Treatment results of bisphosphonate-related osteonecrosis of the jaws. Head Neck. 2008;30(9):1224-30.

187. Gasparini G, Saponaro G, Di Nardo F, Moro A, Boniello R, Cervelli D, et al. Clinical experience with spiramycin in bisphosphonate-associated osteonecrosis of the jaw. Int J Immunopathol Pharmacol. 2010;23(2):619-26.

188. Vescovi P, Manfredi M, Merigo E, Meleti M, Fornaini C, Rocca JP, et al. Surgical approach with Er:YAG laser on osteonecrosis of the jaws (ONJ) in patients under bisphosphonate therapy (BPT). Lasers Med Sci. 2010;25(1):101-13.

189. Vescovi P, Campisi G, Fusco V, Mergoni G, Manfredi M, Merigo E, et al. Surgery-triggered and non surgery-triggered Bisphosphonate-related Osteonecrosis of the Jaws (BRONJ): A retrospective analysis of 567 cases in an Italian multicenter study. Oral Oncol. 2011;47(3):191-4.

190. Vescovi P, Manfredi M, Merigo E, Guidotti R, Meleti M, Pedrazzi G, et al. Early surgical laserassisted management of bisphosphonate-related osteonecrosis of the jaws (BRONJ): a retrospective analysis of 101 treated sites with long-term follow-up. Photomed Laser Surg. 2012;30(1):5-13.

191. Graziani F, Vescovi P, Campisi G, Favia G, Gabriele M, Gaeta GM, et al. Resective surgical approach shows a high performance in the management of advanced cases of bisphosphonate-related osteonecrosis of the jaws: a retrospective survey of 347 cases. J Oral Maxillofac Surg. 2012;70(11):25017.

192. Harper RP, Fung E. Resolution of bisphosphonate-associated osteonecrosis of the mandible: possible application for intermittent low-dose parathyroid hormone [rhPTH(1-34)]. J Oral Maxillofac Surg. 2007;65(3):573-80.

193. Lau AN, Adachi JD. Resolution of osteonecrosis of the jaw after teriparatide [recombinant human PTH-(1-34)] therapy. J Rheumatol. 2009;36(8):1835-7.

194. Narongroeknawin P, Danila MI, Humphreys LG, Barasch A, Curtis JR. Bisphosphonateassociated osteonecrosis of the jaw, with healing after teriparatide: a review of the literature and a case report. Spec Care Dentist. 2010;30(2):77-82.

195. Tsai KY, Huang CS, Huang GM, Yu CT. More on the resolution of bisphosphonate-associated osteonecrosis of the jaw. J Rheumatol. 2010;37(3):675; author reply 6.

196. Cheung A, Seeman E. Teriparatide therapy for alendronate-associated osteonecrosis of the jaw. N Engl J Med. 2010;363(25):2473-4.

197. Lee JJ, Cheng SJ, Jeng JH, Chiang CP, Lau HP, Kok SH. Successful treatment of advanced bisphosphonate-related osteonecrosis of the mandible with adjunctive teriparatide therapy. Head Neck. 2011;33(9):1366-71.

198. Iwamoto J, Yago K, Sato Y, Matsumoto H. Teriparatide therapy for bisphosphonate-associated osteonecrosis of the jaw in an elderly Japanese woman with severe osteoporosis. Clin Drug Investig. 2012;32(8):547-53.

199. Koorbusch GF, Deatherage JR, Curé JK. How can we diagnose and treat osteomyelitis of the jaws as early as possible? Oral Maxillofac Surg Clin North Am. 2011;23(4):557-67, vii. 
200. El-Maghraby TA, Moustafa HM, Pauwels EK. Nuclear medicine methods for evaluation of skeletal infection among other diagnostic modalities. Q J Nucl Med Mol Imaging. 2006;50(3):167-92.

201. Johnston B, Conly J. Osteomyelitis management: More art than science? Can J Infect Dis Med Microbiol. 2007;18(2):115-8. 


\section{Figure legend}

$\mathrm{BPs}=$ bisphosphonates $\mathrm{HBO}=$ hyperbaric oxygen.

Figure 1: Propose diagnostic criteria for OMJ 
Figure 1.

Before BP initiation

At risk: $\mathrm{BP}$ administration

Absence of exposed bone but

Treatment

symptomatic stage

2009 AAOMS strategy

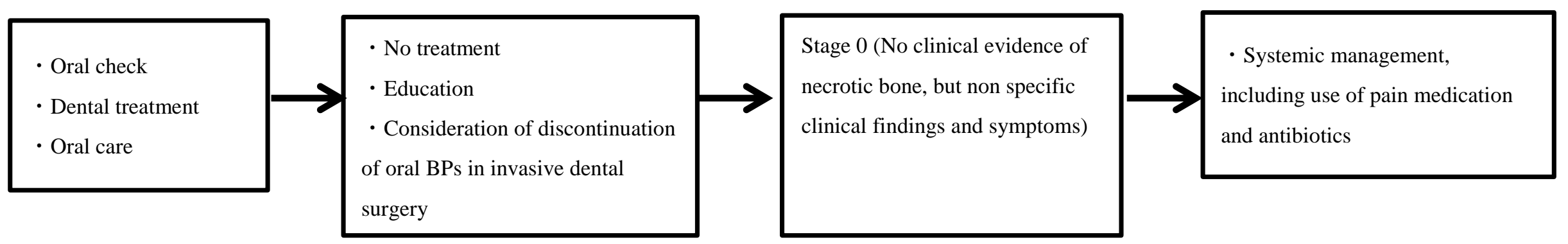

Our strategy

\begin{tabular}{|l|l|l|l|l|}
\hline$\cdot$ Oral check \\
$\cdot$ Education \\
- Dental treatment \\
Oral care
\end{tabular}


Table 1. Characteristics of studies of cumulative risk of bisphosphonate-related osteomyelitis of the jaw among patients taking intravenous bisphosphonates

\begin{tabular}{|c|c|c|c|c|c|c|c|c|c|c|}
\hline Published year & 2003 & 2004 & 2005 & 2006 & 2007 & 2008 & 2009 & 2010 & 2011 & 2012 \\
\hline No. of studies & 0 & 0 & 2 & 4 & 14 & 18 & 14 & 9 & 17 & 13 \\
\hline Country & USA & Italy & Greece & \multicolumn{2}{|c|}{ International } & Germany & Canada & Australia & Japan & Others \\
\hline No. of studies & 24 & 18 & 8 & \multicolumn{2}{|c|}{7} & 6 & 4 & 4 & 3 & 19 \\
\hline Setting & Hospital & \multicolumn{2}{|c|}{ Multi-center } & \multicolumn{2}{|c|}{ Single-center* } & \multicolumn{2}{|c|}{ Health insurance data } & \multicolumn{2}{|c|}{ Population-based } & Others \\
\hline No. of studies & 55 & \multicolumn{2}{|c|}{20} & \multicolumn{2}{|c|}{6} & \multicolumn{2}{|c|}{6} & \multicolumn{2}{|c|}{2} & 2 \\
\hline Type of study & \multicolumn{2}{|c|}{ Meta-analysis } & RCT & \multicolumn{2}{|c|}{ Cohort } & v/o control & \multicolumn{2}{|c|}{ Case control } & \multicolumn{2}{|c|}{ Cross-sectional } \\
\hline No. of studies & \multicolumn{2}{|c|}{1} & 21 & \multicolumn{2}{|c|}{5} & 59 & \multicolumn{2}{|c|}{2} & \multicolumn{2}{|c|}{3} \\
\hline Target population & $\mathrm{BC}$ & MM & $\mathrm{PC}$ & $\mathrm{LC}$ & \multicolumn{2}{|c|}{ Cancer complex } & \multicolumn{3}{|c|}{ Osteoporosis or Paget disease } & Others \\
\hline No. of studies & 18 & 15 & 8 & 2 & \multicolumn{2}{|r|}{37} & \multicolumn{3}{|c|}{5} & 6 \\
\hline No. of population & \multicolumn{2}{|c|}{$<100$} & \multicolumn{2}{|c|}{$100-500$} & \multicolumn{2}{|c|}{$500-1000$} & \multicolumn{2}{|c|}{$1000-5000$} & \multicolumn{2}{|c|}{$5000>$} \\
\hline No. of studies & \multicolumn{2}{|c|}{28} & \multicolumn{2}{|c|}{28} & \multicolumn{2}{|c|}{10} & \multicolumn{2}{|c|}{15} & \multicolumn{2}{|c|}{10} \\
\hline Main endpoint & \multicolumn{3}{|c|}{ BROMJ } & \multicolumn{3}{|c|}{ SRE including BROMJ } & \multicolumn{4}{|c|}{ Codes of surgery or inflammation of the jaw } \\
\hline No. of studies & \multicolumn{3}{|c|}{47} & & 39 & & & & & \\
\hline Diagnostician & Sur & ons or onc & & Dentists & Physici & Inv & tigators or $\mathrm{c}$ & nmittee & Others & Unclear \\
\hline
\end{tabular}




\begin{tabular}{|c|c|c|c|c|}
\hline Search procedure & \multicolumn{2}{|c|}{ From pharmacy or prescription records } & From medical or dental records & Marketing information \\
\hline No. of studies & \multicolumn{2}{|c|}{79} & 9 & 3 \\
\hline Evidence grade & 1a (meta-analysis) & $1 \mathrm{~b}(\mathrm{RCT})$ & 2 or 3 (controlled study) & 4 (quasi-experimental study) \\
\hline No. of studies & 1 & 21 & 7 & 62 \\
\hline publication lists & 98 & $\begin{array}{l}61,69,72,80,93,96,101,104, \\
105,108,111-113,115,116,119, \\
120,122,123,134,135\end{array}$ & $37,49,53,54,106,118,133$ & $\begin{array}{l}10,31,32,34-36,55-60,62-71,73-79, \\
81-92,94,95,97,99,100,102,103, \\
107,109,110,114,117,121,124-132\end{array}$ \\
\hline
\end{tabular}

$\mathrm{BC}=$ breast cancer BPs = Bisphosphonate BROMJ = bisphosphonate-related osteomyelitis of the jaw; LC = lung cancer; $\mathrm{MM}=$ multiple myeloma; $\mathrm{PC}=$ prostate cancer; RCT = randomized clinical trial; SRE = skeletal-related events; w/o = without.

* Studies were conducted in a single center, excluded hospitals. 
Table 2. Incidence of bisphosphonate-related osteomyelitis of the jaw among patients taking intravenous bisphosphonates in studies with an evidence level of 1

\begin{tabular}{|c|c|c|c|c|c|c|c|c|c|}
\hline No. & Author & Setting & Target & Kind of BP & $\begin{array}{c}\text { End } \\
\text { point* }\end{array}$ & Diagnosis & Outcomes/users & Incidence (\%) & Evidence \\
\hline 98 & Mauri & N.A. & $\mathrm{BC}$ & P, ZA, I, C, R & 0 & unclear & $13 / 3,987$ & 0.2 & $1 \mathrm{a}$ \\
\hline 61 & Lyles & $\mathrm{MC}$ & $\mathrm{HF}$ & $\mathrm{ZA}$ & 1 & physicians & $0 / 1,054$ & 0.0 & $1 b$ \\
\hline 69 & Grbric & $\mathrm{MC}$ & OSP & $\mathrm{ZA}$ & 1 & $\mathrm{AC}$ & $1 / 3,875$ & 0.03 & $1 \mathrm{~b}$ \\
\hline 72 & Brufsky & $\mathrm{MC}$ & $\mathrm{BC}$ & $\mathrm{ZA}$ & 1 & unclear & $0 / 1,652$ & 0.0 & $1 b$ \\
\hline 80 & Musto & $\mathrm{MC}$ & MM & $\mathrm{ZA}$ & 1 & unclear & $1 / 81$ & 1.2 & $1 b$ \\
\hline 93 & Hines & $\mathrm{SC}$ & $\mathrm{BC}$ & $\mathrm{ZA}$ & 1 & OMS & $1 / / 274$ & 0.4 & $1 \mathrm{~b}$ \\
\hline 96 & Brufsky & $\mathrm{MC}$ & $\mathrm{BC}$ & $\mathrm{ZA}$ & 1 & $\mathrm{AC}$ of $\mathrm{ONJ}$ & $0 / 301$ & 0.0 & $1 \mathrm{~b}$ \\
\hline 101 & Guarneri & $\mathrm{MC}$ & $\mathrm{BC}$ & $\begin{array}{l}\text { P, ZA, C } \\
\text { with BV }\end{array}$ & 1 & unclear & $2 / 233-10 / 425$ & $0.9-2.4$ & $1 \mathrm{~b}$ \\
\hline 104 & Gimsing & $\mathrm{MC}$ & MM & $\mathrm{P}$ & 1 & questionnaire & $\begin{array}{l}\text { 30mg: } 2 / 252 \text {, } \\
\text { 90mg: } 8 / 250\end{array}$ & $\begin{array}{l}30 \mathrm{mg}: 0.8, \\
90 \mathrm{mg}: 3.2\end{array}$ & $1 \mathrm{~b}$ \\
\hline 105 & Stopeck & $\mathrm{MC}$ & $\mathrm{BC}$ & ZA, DMAB & 1 & $\mathrm{AC}$ of $\mathrm{ONJ}$ & $\begin{array}{c}\text { ZA: } 14 / 1,013, \\
\text { DMAB: } 20 / 1,026\end{array}$ & $\begin{array}{c}\text { ZA: } 1.4, \\
\text { DMAB: } 2.0\end{array}$ & $1 \mathrm{~b}$ \\
\hline 108 & Morgan & $\mathrm{MC}$ & MM & $\mathrm{ZA}, \mathrm{C}$ & 1 & dentists & $\begin{array}{c}\text { ZA: } 35 / 983 \text {, } \\
\text { C: } 3 / 979\end{array}$ & $\begin{array}{c}\text { ZA: } 3.5, \\
\text { C: } 0.3\end{array}$ & $1 \mathrm{~b}$ \\
\hline 111 & Henry & $\mathrm{MC}$ & $\mathrm{CA}, \mathrm{MM}$ & ZA, DMAB & 1 & $\mathrm{AC}$ of $\mathrm{ONJ}$ & $\begin{array}{c}\text { ZA: 11/878, } \\
\text { DMAB: 10/878 }\end{array}$ & $\begin{array}{c}\text { ZA: } 1.3, \\
\text { DMAB: } 1.1\end{array}$ & $1 b$ \\
\hline 112 & Fizazi & $\mathrm{MC}$ & PC & ZA, DMAB & 1 & $\mathrm{AC}$ & $\begin{array}{c}\text { ZA: } 12 / 945, \\
\text { DMAB: } 22 / 943\end{array}$ & $\begin{array}{c}\text { ZA: } 1.2, \\
\text { DMAB: } 2.3\end{array}$ & $1 \mathrm{~b}$ \\
\hline 113 & Coleman & $\mathrm{MC}$ & $\mathrm{BC}$ & $\mathrm{ZA}$ & 1 & investigators & $11 / 1,590$ & 0.7 & $1 b$ \\
\hline
\end{tabular}




\begin{tabular}{|c|c|c|c|c|c|c|c|c|c|}
\hline 115 & Gnant & $\mathrm{MC}$ & $\mathrm{BC}$ & $\mathrm{ZA}$ & 1 & $\begin{array}{l}\text { investigators or } \\
\text { patients level }\end{array}$ & $0 / 900$ & 0.0 & $1 b$ \\
\hline 116 & Pivot & $\mathrm{SC}$ & $\mathrm{BC}$ & I & 1 & $\begin{array}{c}\text { investigators or } \\
\text { patients level }\end{array}$ & $2 / 334$ & 0.6 & $1 b$ \\
\hline 119 & Saad & MC & $\mathrm{CA}, \mathrm{MM}$ & ZA, DMAB & 1 & $\begin{array}{c}\text { AC of dental } \\
\text { experts }\end{array}$ & $\begin{array}{c}\text { ZA: } 37 / 2,836, \\
\text { DMAB: } 52 / 2,841\end{array}$ & $\begin{array}{c}\text { ZA: } 1.3, \\
\text { DMAB: } 1.8\end{array}$ & $1 b$ \\
\hline 120 & Brufsky & $\mathrm{MC}$ & $\mathrm{BC}$ & $\mathrm{ZA}$ & 1 & $\begin{array}{c}\text { investigators and } \\
\text { AC of ONJ }\end{array}$ & $0 / 602$ & 0.0 & $1 \mathrm{~b}$ \\
\hline 122 & Coleman & $\mathrm{MC}$ & $\mathrm{BC}$ & $\mathrm{ZA}$ & 1 & investigators & $17 / 1,686$ & 1.1 & $1 \mathrm{~b}$ \\
\hline 123 & Safra & $\mathrm{SC}$ & $\mathrm{BC}$ & $\mathrm{ZA}$ & 1 & investigators & $0 / 47$ & 0.0 & $1 b$ \\
\hline 134 & Scagliotti & $\mathrm{MC}$ & LC & ZA, DMAB & 1 & unclear & $\begin{array}{c}\text { ZA: } 3 / 406, \\
\text { DMAB: } 3 / 395\end{array}$ & $\begin{array}{c}\text { ZA: } 0.7, \\
\text { DMAB: } 0.8\end{array}$ & $1 b$ \\
\hline 135 & Scagliotti & MC & LC & $\mathrm{ZA}$ & 1 & investigators & $1 / 226$ & 0.4 & $1 \mathrm{~b}$ \\
\hline
\end{tabular}

$\mathrm{AC}=$ adjudication committee; $\mathrm{BC}=$ breast cancer; $\mathrm{BPs}=$ bisphosphonates; $\mathrm{BV}=$ bevacizumab; $\mathrm{C}=$ clodronate $\mathrm{CA}=$ cancer patients; $\mathrm{DMAB}=$ denosumab; $\mathrm{HF}=$ hip fracture patients; $\mathrm{I}=$ ibandronate; $\mathrm{LC}=$ lung cancer; $\mathrm{MC}=$ multicenter; $\mathrm{MM}=$ multiple myeloma; $\mathrm{N} . \mathrm{A} .=$ not applicable; $\mathrm{OMS}=$ oral and maxillofacial surgeons; $\mathrm{ONJ}=$ osteonecrosis of the jaw; $\mathrm{OSP}=$ osteoporosis; $\mathrm{P}=$ pamidronate; $\mathrm{PC}=$ prostate cancer; $\mathrm{R}=$ risedronate; $\mathrm{SC}=$ single center; $\mathrm{ZA}=$ zoledronic acid.

* Endpoint 0 means ONJ and 1 means skeletal related events including ONJ. 
Table 3. Incidence of bisphosphonate-related osteomyelitis of the jaw among patients taking intravenous bisphosphonates in studies with an evidence level of 2 or 3

\begin{tabular}{|c|c|c|c|c|c|c|c|c|c|}
\hline No. & Author & Setting & Target & $\begin{array}{c}\text { Kind of } \\
\text { BP }\end{array}$ & $\begin{array}{l}\text { End } \\
\text { point* }\end{array}$ & Diagnosis & $\begin{array}{l}\text { Outcomes/ } \\
\text { BPs users }\end{array}$ & $\begin{array}{l}\text { Incidence } \\
\text { (\% or rate) }\end{array}$ & Evidence \\
\hline 37 & Zavras & HIP & CA, MM & $\mathrm{P}, \mathrm{ZA}$ & 2 & ICD-9 code & $20 / 5,850$ & 0.34 & 2 \\
\hline 53 & Tennis & HIP & $\mathrm{CA}$ & $\mathrm{I}, \mathrm{P}, \mathrm{ZA}$ & 0 & $\begin{array}{l}\text { ICD-9 or CPT and } \\
\text { chart review }\end{array}$ & $15 / 2,876$ & $\begin{array}{l}5.3 \text { per } 1,000 \\
\text { person-years }\end{array}$ & 2 \\
\hline 54 & Yamazaki & HOSP & $\mathrm{CA}$ & $\begin{array}{c}\text { INC, } \mathrm{P}, \\
\text { ZA }\end{array}$ & 0 & OMS & $4 / 27$ & $14.8 \dagger$ & 2 \\
\hline 106 & Skrepnek & HIP & CA, OSP & $\mathrm{P}, \mathrm{ZA}$ & 2 & ICD-9 code & $\begin{array}{l}\text { CA: } 12 / 6,276, \\
\text { OSP: } 21 / 2,321\end{array}$ & $\begin{array}{l}\text { CA: } 0.43 \\
\text { OSP: } 0.90\end{array}$ & 2 \\
\hline 133 & Beuselinck & HOSP & RCC & $\mathrm{ZA}$ & 1 & patient level & $5 / 49$ & 9.6 & 2 \\
\hline 49 & Wilkinson & HIP & $\mathrm{CA}$ & $\mathrm{P}, \mathrm{ZA}$ & 2 & ICD-9 code & $95 / 14,349$ & $\begin{array}{c}5.5 \text { per } 100 \\
\text { patients }\end{array}$ & 3 \\
\hline 118 & Baillargeon & HIP & OSP & $\begin{array}{c}\mathrm{E}, \mathrm{I}, \mathrm{P}, \\
\mathrm{ZA}\end{array}$ & 2 & ICD-9 code & $9 / 2,296$ & $\begin{array}{c}0.70 \text { per } 100 \\
\text { patients }\end{array}$ & 3 \\
\hline
\end{tabular}

BPs = bisphosphonates; $\mathrm{CA}=$ cancer patients; $\mathrm{CPT}=$ current procedural terminology; $\mathrm{E}=$ etidronate; HIP = health insurance plan data; HOSP = hospital; $\mathrm{I}=$ ibandronate; INC = incadronate; ICD = international classification of diseases; $\mathrm{MM}=$ multiple myeloma; OMS = oral and maxillofacial surgeons; OSP = osteoporosis; $\mathrm{P}=$ pamidronate; $\mathrm{RCC}=$ renal cell carcinoma patients; $\mathrm{ZA}=$ zoledronic acid.

* Endpoint 0 means osteonecrosis of the jaw (ONJ), 1 means skeletal related events including ONJ, and 2 means jaw surgery or inflammation of the jaw code.

$\uparrow$ Cumulative incidence of bisphosphonate-related osteonecrosis of the jaw after tooth extraction. 
Table 4. Incidence of bisphosphonate-related osteomyelitis of the jaw among patients taking oral bisphosphonates

\begin{tabular}{|c|c|c|c|c|c|c|c|c|c|}
\hline No. & Author & Setting & $\begin{array}{c}\text { Target } \\
\text { population }\end{array}$ & $\begin{array}{l}\text { Kind of BP/ } \\
\text { Route of BP } \\
\text { administration }\end{array}$ & $\begin{array}{l}\text { End } \\
\text { point* }\end{array}$ & Diagnosis & $\begin{array}{l}\text { Outcomes/ } \\
\text { BPs users }\end{array}$ & $\begin{array}{l}\text { Incidence } \\
\text { (\% or rate) }\end{array}$ & Evidence \\
\hline 138 & Wells & N.A. & PW & A & 1 & review of RCTs & N.A. & 0 & $1 \mathrm{a}$ \\
\hline 139 & Wells & N.A. & PW & $\mathrm{R}$ & 1 & review of RCTs & N.A. & 0 & $1 \mathrm{a}$ \\
\hline 136 & Jeffcoat & HOSP & $\begin{array}{l}\text { OSP, } \\
\text { OSPE }\end{array}$ & A & 1 & dentists & $0 / 355$ & 0 & $1 b$ \\
\hline 149 & Paterson & $\mathrm{MC}$ & $\mathrm{BC}$ & $\mathrm{C}$ & 1 & investigators & $1 / 1,662$ & 0.06 & $1 b$ \\
\hline 37 & Zavras & HIP & $\mathrm{CA}$ & $\mathrm{A}, \mathrm{R}$ & 2 & ICD-9 code & $19 / 20,438$ & 0.092 & 2 \\
\hline 51 & Yamazaki & HOSP & OSP & A, E, R & 3 & $\begin{array}{l}\text { ICD-10 and OMS } \\
\text { chart review }\end{array}$ & $21-46 / 4,129$ & $0.46-0.99$ & 2 \\
\hline 53 & Tennis & HIP & OSP & A, E, I, R & 0 & $\begin{array}{l}\text { ICD-9 or CPT and } \\
\text { chart review }\end{array}$ & $2 / 6,319$ & $\begin{array}{l}150 \text { per million } \\
\text { person-years } \dagger\end{array}$ & 2 \\
\hline 54 & Yamazaki & HOSP & OSP & $\mathrm{A}, \mathrm{E}, \mathrm{R}$ & 0 & OMS & $1 / 99$ & $1.0 \%$ & 2 \\
\hline 106 & Skrepnek & HIP & CA, OSP & $\mathrm{A}, \mathrm{E}$ & 2 & ICD-9 code & $\begin{array}{l}79 / 213,364- \\
199 / 213,364\end{array}$ & $0.02-0.09$ & 2 \\
\hline 141 & Sedghizadeh & HOSP & $\begin{array}{c}\text { PT taking } \\
\text { A }\end{array}$ & A & 0 & dentists & $9 / 208$ & 4.3 & 2 \\
\hline 146 & Fellows & HIP & $\begin{array}{c}\mathrm{HP}, \\
\text { KPNW }\end{array}$ & $\mathrm{PO}$ & 0 & $\begin{array}{l}\text { ICD-9 and chart } \\
\text { review }\end{array}$ & $6 / 21,163$ & $\begin{array}{l}6.3 \text { per million } \\
\text { person-years } \dagger\end{array}$ & 2 \\
\hline 151 & Etminan & HIP & OSP & A, E, R & 2 & ICD-9 code & $196 / 87,837$ & $\begin{array}{c}267 \text { per million } \\
\text { person-years }\end{array}$ & 3 \\
\hline
\end{tabular}


$\mathrm{A}=$ alendronate BEST $=$ Bisphosphonates Effectiveness Safety Trade-off network; $\mathrm{BC}=$ breast cancer; $\mathrm{BPs}=$ bisphosphonates; $\mathrm{C}=$ clodronate; $\mathrm{CA}=$ cancer patients; $\mathrm{CPT}=$ current procedural terminology; $\mathrm{E}=$ etidronate; HIP = health insurance plan data; HP = Health Partners of Minnesota; HOSP = hospital; KPNW = Kaiser Permanente Northwest; I = ibandronate; ICD = international classification of diseases; $\mathrm{MC}=$ multicenter; N.A. $=$ not applicable; OMS = oral and maxillofacial surgery; OSP = osteoporosis; OSPE = osteopenia $\mathrm{PO}=$ per os; $\mathrm{PT}=$ patients; $\mathrm{PW}=$ postmenopausal women; $\mathrm{R}=$ risedronate; $\mathrm{RCT} ;=$ randomized clinical trial.

* Endpoint 0 means osteonecrosis of the jaw (ONJ), 1 means skeletal related events including ONJ, 2 means jaw surgery or inflammation of the jaw code, and 3 means osteomyelitis of the jaw.

† To convert an incidence rate to "per million person-years," we simply multiplied.

$\uparrow$ Cumulative incidence of bisphosphonate-related ONJ after tooth extraction. 
Table 5. Relative risk of bisphosphonates for osteomyelitis of the jaw

\begin{tabular}{|c|c|c|c|c|c|c|c|c|c|c|}
\hline No. & Author & Setting & $\begin{array}{c}\text { Target } \\
\text { population }\end{array}$ & $\begin{array}{c}\text { Route of BP } \\
\text { administration }\end{array}$ & $\begin{array}{c}\text { End } \\
\text { point* }\end{array}$ & $\begin{array}{c}\text { Population } \\
\text { no. }\end{array}$ & $\begin{array}{l}\text { Risk } \\
\text { index }\end{array}$ & Risk ratio $[95 \% \mathrm{CI}]$ & $\begin{array}{c}\text { Adjust- } \\
\text { ment }\end{array}$ & Evidence \\
\hline 49 & Wilkinson & HIP & $\mathrm{CA}$ & IV & 2 & 44,771 & HR & $11.5[6.5-20.3]$ & yes & 3 \\
\hline 118 & Baillargeon & HIP & OSP & IV & 0 & 9,161 & HR & $1.6[0.71-3.8]$ & yes & 3 \\
\hline \multirow[t]{2}{*}{37} & Zavras & HIP & $\mathrm{CA}$ & IV/PO & 2 & 5,850 & $\mathrm{RR}$ & IV: 4.2 [2.7-6.7] & no & 2 \\
\hline & & & & & & & & PO: 1.2 [0.7-1.8] & & \\
\hline 52 & & & OSP & $\mathrm{PO}$ & & & & PO: 0.65 [0.54-0.79] & & \\
\hline \multirow[t]{2}{*}{53} & Tennis & HIP & $\mathrm{CA}$ & IV & 0 & 46,542 & OR & IV: 8.8 [2.0-38] & yes & 2 \\
\hline & & & OSP & $\mathrm{PO}$ & & & & PO: $0.15[0.00-0.36]$ & & \\
\hline \multirow[t]{2}{*}{54} & Yamazaki & HOSP & $\mathrm{TE}$ & IV & 0 & 3,216 & $\mathrm{RR}$ & IV: 200.2 [23.8-1679] & yes & 2 \\
\hline & & & & $\mathrm{PO}$ & & & & PO: 12.9 [0.82-204] & & \\
\hline \multirow[t]{2}{*}{153} & Barasch & PBRN & $\mathrm{CA}+\mathrm{OSP}$ & IV & 2 & 764 & OR & IV: 299.5 [70-1282] & yes & 3 \\
\hline & & & & $\mathrm{PO}$ & & & & PO: 12.2 [4.3-35] & & \\
\hline \multirow[t]{2}{*}{50} & Vestergaard & NR & OSP & $\mathrm{PO}$ & 0 & 414,245 & HR & A: 3.2 [1.4-6.9] & yes & 3 \\
\hline & & & & & & & & E: $2.2[1.2-4.3]$ & & \\
\hline 51 & Yamazaki & HOSP & OSP & $\mathrm{PO}$ & 3 & 6,923 & OR & $5.0[1.9-12.9]$ & yes & 2 \\
\hline \multirow[t]{2}{*}{146} & Fellows & HIP & $\mathrm{HP}$ & $\mathrm{PO}$ & 0 & 572,606 & OR & $15.5[6.0-38.7]$ & no & 2 \\
\hline & & & KPNW & & & & & & & \\
\hline 152 & Lapi & BEST & OSP & $\mathrm{PO}$ & 0 & 65,220 & OR & $2.8[1.3-5.9]$ & yes & 3 \\
\hline \multirow[t]{2}{*}{151} & Etminan & HIP & OSP & $\mathrm{PO}$ & 2 & 87,837 & $\mathrm{RR}$ & A: $2.9[1.7-5.1]$ & yes & 3 \\
\hline & & & & & & & & E: $2.4[1.0-5.6]$ & & \\
\hline
\end{tabular}




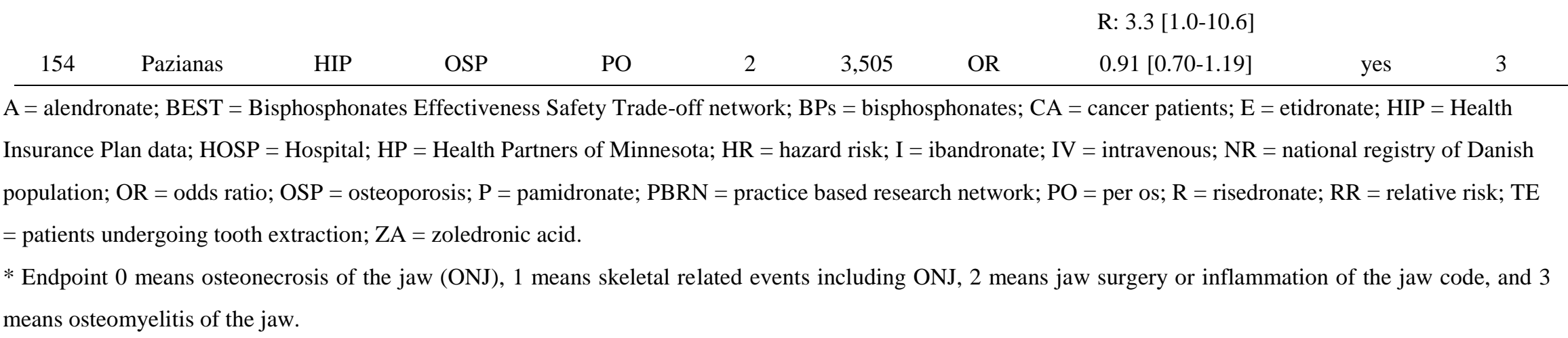


Table 6. Risk factors of bisphosphonate-related osteomyelitis of the jaw

\begin{tabular}{lll}
\hline Risk factor & \multicolumn{1}{c}{$\begin{array}{c}\text { Publication lists of controlled studies with adjustment for covariates } \\
\text { Positive association }\end{array}$} \\
\hline Gender & 164 & $35,49,53,54,56,60,70,71,91,100$ \\
Age & 38,165 & $31,49,53,54,56,70,71,75,91,100,164$ \\
Race & 117,165 & \\
Smoking & 125,160 & $75,91,163$ \\
Alcohol & 167 & $54,75,160$ \\
Primary illness & & \\
Diabetes & $50,125,156,159$ & $56,128,110,146,160$ \\
Hypertension & & 56,160 \\
Use of BPs & $31,35,36,49,57,75,91,125,153,161,164,165,168$ \\
Duration/cycle of BPs & $31,35,36,38,49,50,52,54,75,91,125,160,164,181$ & $50,86,87,152,154,158$ \\
BPs with high potency & & 154,158 \\
Use of other drugs & $50,56,60,161$ & \\
Cancer chemotherapy & 172 & $54,63,70,75,110,153,158,160,162$ \\
Corticosteroids & 35 & $53,54,56,70,86,110,125,128,153,158,160$ \\
Thalidomide & & $31,70,71,86,110$ \\
Oral status & $38,70,75,91,128,153,162,163$ & $91,153,159,163$ \\
Tooth extraction & 54,162 & 128,165 \\
Periodontitis/Oral hygiene & $91,163,167$ & \\
Use of denture & &
\end{tabular}

BPs $=$ bisphosphonates 
Table 7. Treatment of bisphosphonate-related osteomyelitis of the jaw

\begin{tabular}{|c|c|c|c|c|c|c|c|c|}
\hline ID & Author & Treatment & Setting & Target & Kinds of BP & $\begin{array}{l}\text { Population } \\
\text { no. }\end{array}$ & Improvements & Evidence \\
\hline 185 & Freiberger & HBO therapy & REC & BRONJ & $\mathrm{P}, \mathrm{ZA}, \mathrm{A}$ & 46 & time to healing, pain, QOL & $1 b$ \\
\hline 79 & Montefusco & $\begin{array}{c}\text { antibiotic prophylaxis v.s. } \\
\text { none }\end{array}$ & HOSP & MM & $\mathrm{P}, \mathrm{ZA}$ & 178 & reduction of BRONJ incidence & 2 \\
\hline 171 & Atalay & $\begin{array}{l}\text { Laser-assisted v.s. } \\
\text { conventional surgery }\end{array}$ & HOSP & BRONJ & $\mathrm{ZA}$ & 20 & $\begin{array}{c}\text { no statistically significant } \\
\text { difference between two } \\
\text { surgeries }\end{array}$ & 2 \\
\hline 186 & Wutzl & Surgical treatment & HOSP & BRONJ & $\mathrm{P}, \mathrm{ZA}, \mathrm{A}, \mathrm{I}, \mathrm{R}$ & 58 & stages after surgery & 2 \\
\hline 187 & Gasparini & Spiramycin v.s. ACA & HOSP & BRONJ & unclear & 25 & clinical outcomes & 2 \\
\hline 188 & Vescovi & Er:YAG laser surgery & HOSP & BRONJ & unclear & 91 & clinical outcomes & 2 \\
\hline 189 & Vescovi & Surgical treatment & $\mathrm{MC}$ & BRONJ & $\mathrm{P}, \mathrm{ZA}, \mathrm{A}$, others & 567 & clinical outcomes & 2 \\
\hline 190 & Vescovi & $\begin{array}{c}\text { Medical and surgical } \\
\text { therapy }\end{array}$ & HOSP & BRONJ & unclear & 128 & clinical outcomes & 2 \\
\hline 191 & Graziani & Surgical intervention & HOSP & BRONJ & $\begin{array}{c}\mathrm{P}, \mathrm{ZA}, \mathrm{A}, \mathrm{C}, \mathrm{I} \\
\mathrm{N}, \mathrm{R}\end{array}$ & 347 & clinical outcomes* & 3 \\
\hline
\end{tabular}

$\mathrm{A}=$ alendronate $\mathrm{ACA}=$ amoxicillin and clavulanic acid $; \mathrm{BPs}=$ bisphosphonates $; \mathrm{BRONJ}=$ bisphosphonate-related osteonecrosis of the jaw; $\mathrm{C}=\mathrm{clodronate} ; \mathrm{E}=$ etidronate; Er: YAG = erbium-doped yttrium aluminum garnet; $\mathrm{HBO}=$ hyperbaric oxygen; HOSP = Hospital; HR = hazard risk; I = ibandronate; IV = intravenous; $\mathrm{MC}=$ multicenter; $\mathrm{MM}=$ multiple myeloma; $\mathrm{N}=$ neridronate $\mathrm{P}=$ pamidronate $; \mathrm{PO}=$ per os $; \mathrm{QOL}=$ quality of life $\mathrm{R}=$ risedronate $\mathrm{REC}=$ recruitment nationwide; $\mathrm{ZA}=$ zoledronic acid.

* The result was estimated by odds ratios adjusted for age, gender, stage, and use of corticosteroids. 
